US Army Corps of Engineers ${ }_{\circledast}$

Engineer Research and

Development Center

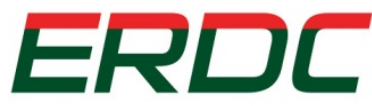

INNOVATIVE SOLUTIONS for a safer, better world

DoD Corrosion Prevention and Control Program

\title{
Demonstration of Thermally Sprayed Metal and Polymer Coatings for Steel Structures at Fort Bragg, NC
}

Final Report on Project F07-AR10

Larry D. Stephenson, Alfred D. Beitelman, Richard G. Lampo,

Ashok Kumar, Douglas Neale, Lawrence Clark, Karl Palutke,

Michael Surratt, and David Butler

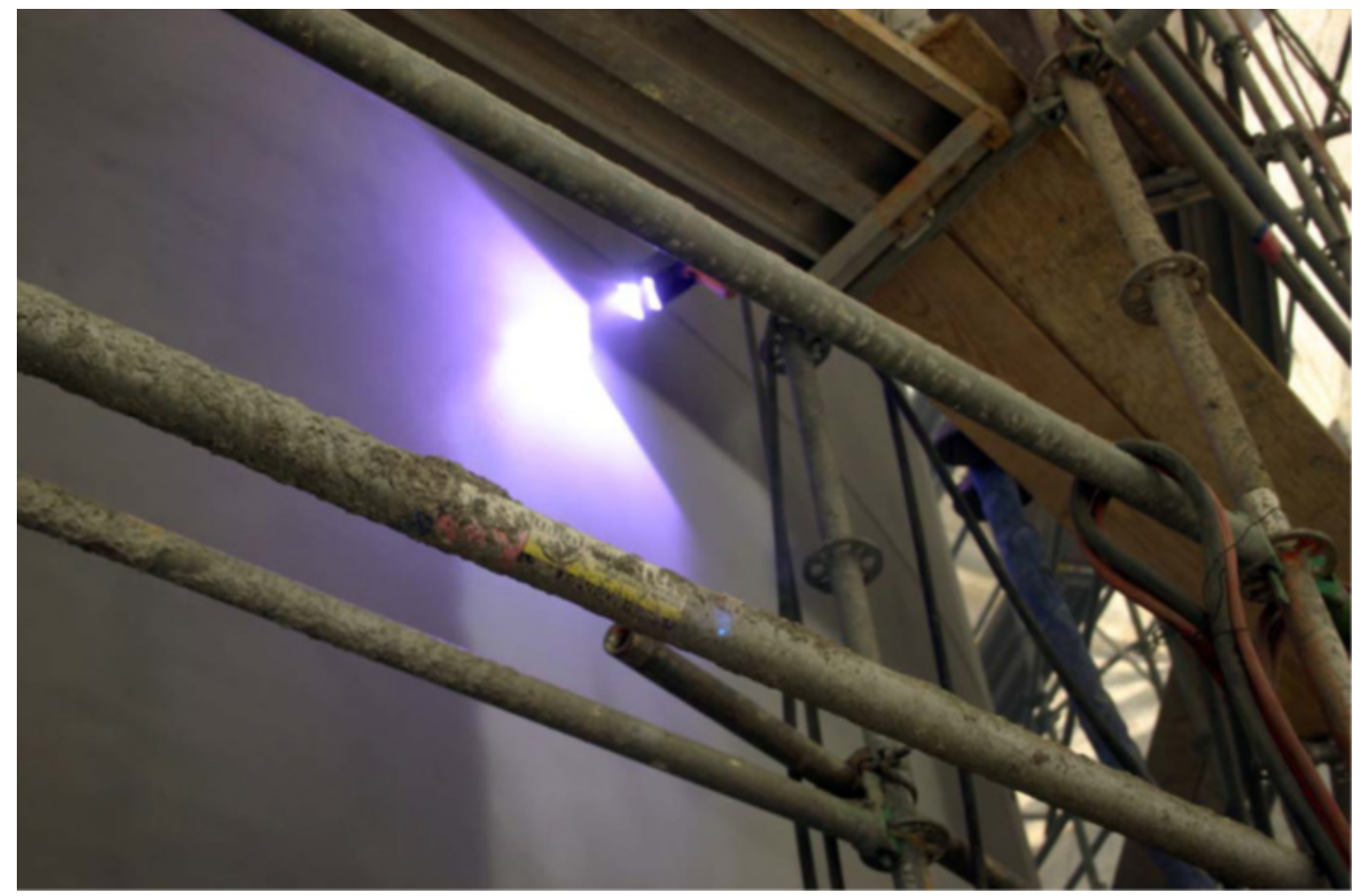


The U.S. Army Engineer Research and Development Center (ERDC) solves the nation's toughest engineering and environmental challenges. ERDC develops innovative solutions in civil and military engineering, geospatial sciences, water resources, and environmental sciences for the Army, the Department of Defense, civilian agencies, and our nation's public good. Find out more at www.erdc.usace.army.mil.

To search for other technical reports published by ERDC, visit the ERDC online library at http://acwc.sdp.sirsi.net/client/default. 


\section{Demonstration of Thermally Sprayed Metal and Polymer Coatings for Steel Structures at Fort Bragg, NC}

Final Report on Project F07-AR10

Larry D. Stephenson, Alfred D. Beitelman, Richard G. Lampo, and Ashok Kumar

Construction Engineering Research Laboratory

U.S. Army Engineer Research and Development Center

2902 Newmark Drive

Champaign, IL 61822

Douglas Neale, Lawrence Clark, Karl Palutke, Michael Surratt, and David Butler

Mandaree Enterprise Corporation

812 Park Drive

Warner Robins, GA 31088

Final report

Approved for public release; distribution is unlimited.

Prepared for Office of the Secretary of Defense (OUSD(AT\&L))

3090 Defense Pentagon

Washington, DC 20301-3090

Under Project F07-AR10, “Long-life Thermal Spray Coatings for Metal Structures for Fuel Tank at Fort Campbell" 


\section{Abstract}

The Department of Defense spends billions annually on corrosion-related maintenance. It has recently been estimated that at least 25 U.S. Army installations have severe corrosion problems with above-ground steel storage tanks. Coatings are widely recognized as a "first line of defense" for protecting these steel structures. Thus, the Office of the Secretary of Defense Corrosion Prevention and Control Program sponsored a project that demonstrated and evaluated new technology with two thermally sprayed coating systems for corrosion protection of steel structures in severely corrosive environments. The technologies included metallizing a steel tank with zinc-aluminum alloy and flame-spraying a polyolefin powder coating on the legs of an elevated steel storage tank. This report documents the materials and application of the two coating systems and subsequent performance evaluations. Metallizing is more costly than traditional organic coatings and is often overlooked as an option. However, life-cycle costs in highly corrosive environments can actually be lower than using organic coating systems. As this project demonstrated, the flame-sprayed polyolefin coating is too costly for use on large steel structures. Guidance documents are identified to help make decisions on the use and procurement of metallizing coating systems. The project's return on investment was calculated to be 2.94 . 


\section{Table of Contents}

List of Figures and Tables

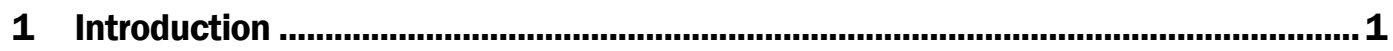

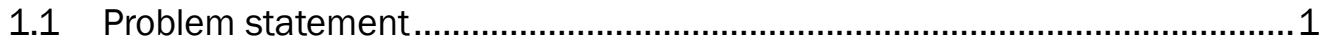

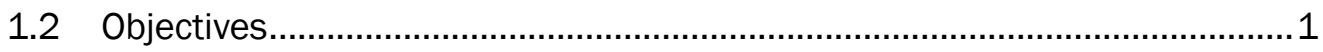

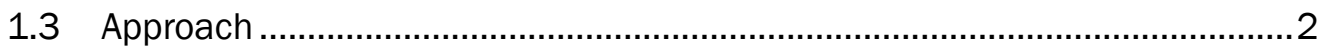

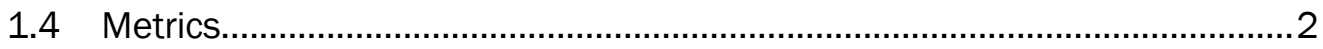

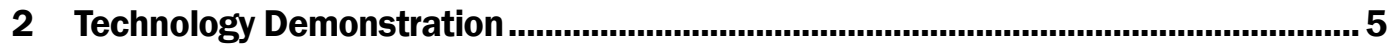

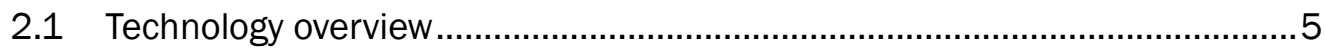

2.1.1 Metallized coating....................................................................................... 5

2.1.2 Thermoplastic polymer coating (flame spray) ...................................................... 6

2.1.3 Material specifications ....................................................................................... 7

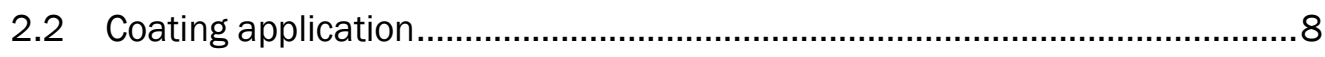

2.2.1 Heating plant fuel tank ............................................................................... 8

2.2.2 Elevated steel water tank legs .......................................................................... 11

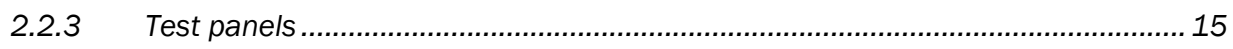

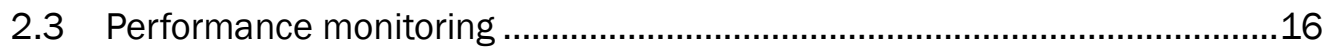

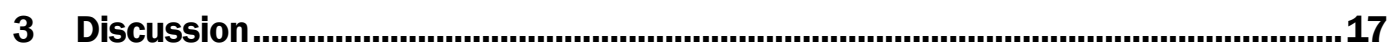

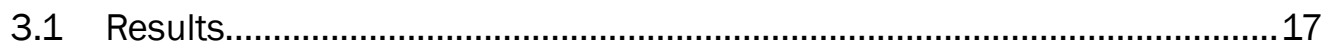

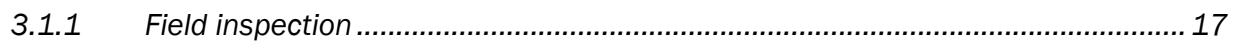

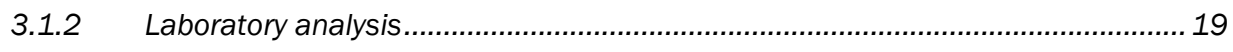

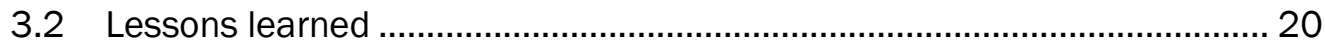

3.2.1 Application issues ................................................................................... 21

3.2.2 Operational issues .................................................................................... 21

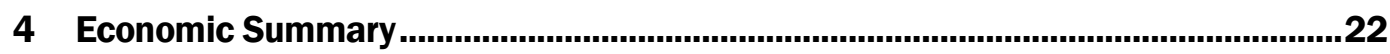

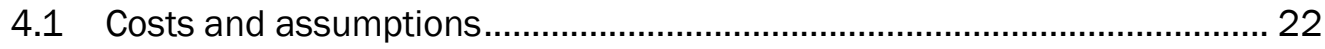

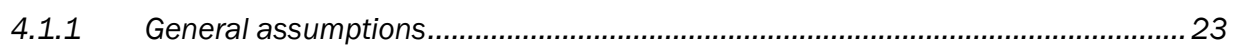

4.1.2 Alternative 1 (baseline scenario) ................................................................... 23

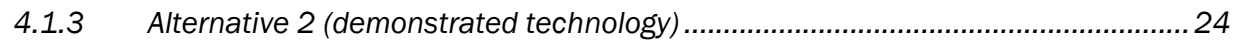

4.2 Projected return on investment (ROI) .....................................................24

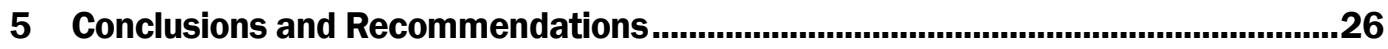

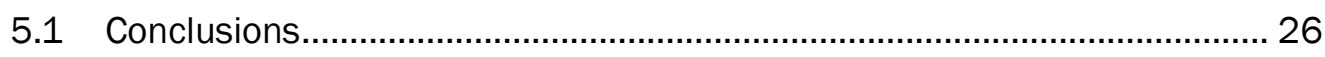

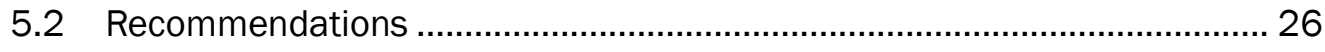

5.2.1 Applicability ...................................................................................... 26 


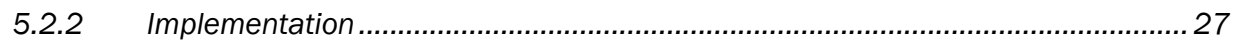

Appendix A: Platt Bros. 85/15 Metallizing Wire Technical Data ................................29

Appendix B: Sherwin-Williams “SHER-CRY"” Topcoat Technical Data ...........................33

Appendix C: Plascoat PPA 571 Ethylene Acrylic Acid-Modified Polyolefin

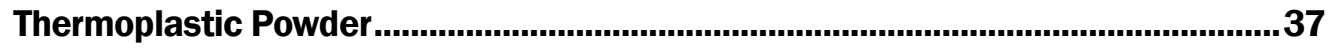

Report Documentation Page 


\section{List of Figures and Tables}

\section{Figures}

Figure 1. Heating plant fuel tank for application of the zinc-aluminum coating. 6

Figure 2. Elevated water-storage tank (left) with close-up (right) showing the support legs on which the polyolefin powder coating was to be applied.

Figure 3. Heating plant's fuel tank with containment installed (background).

Figure 4. Inside of scaffolding and tarp enclosure around the heating plant's tank.

Figure 5. Thermal arc spray application of 85/15 alloy.

Figure 6 . Water tower leg with containment being installed prior to abrasive blasting.

Figure 7. Water tower leg containment during abrasive blast.

Figure 8. Application of EAA-modified polyolefin powder coating (lighter color) with flame spray.

Figure 9. Polyolefin coating (lighter color) applied on water tower leg.

Figure 10. Polyolefin powder being added through a sifter to the hopper of a flame-spray unit to remove any large particles.

Figure 11. Exterior exposure test panels: Polyolefin coating, bottom row from left; zinc-aluminum metallized coating sealed with acrylic topcoat - bottom row, right).

Figure 12. Heating plant's fuel tank, as inspected on 6 May 2015. The visible, dark areas are dirt and algae staining.

Figure 13. One of the elevated water tower's legs finished with the flame-sprayed polyolefin coating, as inspected on 6 May 2015

\section{Tables}

Table 1. Polyolefin coating requirements.

Table 2. Results of laboratory analysis of exposure panels.

Table 3. Breakdown of total project costs for the demonstration of long-life thermal spray coatings.

Table 4. Long-life thermal spray coatings project costs for the contracted field work.

Table 5. Projected ROI. 


\section{Preface}

This demonstration was performed for the Office of the Secretary of Defense (OSD) under Corrosion Prevention and Control (CPC) Program Project Fo7-AR10, "Long-life Thermal Spray Coatings for Metal Structures for Fuel Tank at Fort Campbell." Note that prior to execution, this project was moved from Fort Campbell, Kentucky, to Fort Bragg, North Carolina. The proponent was the U.S. Army Office of the Assistant Chief of Staff for Installation Management (ACSIM), and the stakeholder was the U.S. Army Installation Management Command (IMCOM). The technical monitors were Daniel J. Dunmire (OUSD(AT\&L)), Bernie Rodriguez (IMPW-E), and Valerie D. Hines (DAIM-ODF).

The work was performed by the Materials and Structures Branch (CEERDCFM) of the Facilities Division (CF), U.S. Army Engineer Research and Development Center, Construction Engineering Research Laboratory (ERDC-CERL). The ERDC-CERL CPC Program Manager was Michael K. McInerney. A portion of the work was performed by Mandaree Enterprise Corporation (MEC), Warner Robins, Georgia. The principal subcontractors for all coating applications were Donald Martin, Martin's Commercial and Industrial; Adam Brown, J\&W of NC; and Earl Snyder, Corrosion Preventive Services. At the time of publication, Vicki L. Van Blaricum was Chief, CEERD-CFM; Donald K. Hicks was Chief, CEERD-CF; and Kurt J. Kinnevan, CEERD-CVT, was Technical Director for Installations. The Deputy Director of ERDC-CERL was Dr. Kirankumar Topudurti, and the Director was Dr. Ilker Adiguzel.

The following personnel are gratefully acknowledged for their support and assistance in this project:

- Russell Hayes - Mechanical Engineer Directorate of Public Works (DPW), Fort Bragg, NC

- Gene Foster - Field Service Leader, Honeywell Building Solutions, Fort Bragg, NC

- All personnel at the Fort Bragg heating plant

The Commander of ERDC was COL Bryan S. Green, and the Director was Dr. David W. Pittman. 


\section{Unit Conversion Factors}

\begin{tabular}{|l|c|l|}
\hline Multiply & By & To Obtain \\
\hline degrees Fahrenheit & (F-32)/1.8 & degrees Celsius \\
\hline feet & 0.3048 & meters \\
\hline gallons (U.S. liquid) & 3.785412 E-03 & cubic meters \\
\hline inches & 0.0254 & meters \\
\hline mils & 0.0254 & millimeters \\
\hline square feet & 0.09290304 & square meters \\
\hline pounds per square inch & 0.006894757 & megapascal \\
\hline
\end{tabular}


(Intentionally blank.) 


\section{Introduction}

\subsection{Problem statement}

Billions of dollars are annually spent dealing with the effects of corrosion on Department of Defense (DoD) infrastructure facilities (Herzberg, Kelly, and O'Heara 2010). Coatings are widely recognized as a "first line of defense" for protecting steel structures from corrosion.

Severe corrosion problems were identified on several above-ground steel fuel- and water-storage tanks at Fort Bragg, North Carolina. These deteriorating structures needed to be rehabilitated before they begin to fail, which would cause leaks or lead to other types of catastrophic failure. It is estimated that 25 other U.S. Army installations have similar problems with above-ground steel storage tanks. Further, because corrosion is inevitable and all corrosion-control systems have a finite life cycle, it can be reasonably assumed that similar corrosion problems on steel structures must be addressed at virtually all U.S. military installations worldwide.

Fuel- and water-storage tanks are defined as critical infrastructure, so there is an urgent need to evaluate emerging protective coating technologies that improve corrosion control and reduce maintenance costs. The DoD's Corrosion Prevention and Control (CPC) Program supports demonstrations of emerging technologies for prospective implementation by the military services. This report documents a demonstration and evaluation of the effectiveness and cost of two innovative corrosion-control technologies, performed under the CPC Program by the U.S. Army Engineer Research and Development Center, Construction Engineering Research Laboratory (ERDC-CERL).

\subsection{Objectives}

The objective of this project was to demonstrate and evaluate two thermal spray coating technologies and their performance for the corrosion protection of steel structures. The two demonstrated technologies were as follows:

- Thermal arc-sprayed zinc-aluminum alloy (to provide galvanic protection of the steel substrates) 
- Flame-sprayed ethylene acrylic acid (EAA)-modified polyolefin powder coating.

\subsection{Approach}

The thermal arc-sprayed zinc-aluminum alloy was selected to be applied to a steel heating plant fuel tank serving the $82^{\text {nd }}$ Airborne Division at Fort Bragg. The tank was grit-blasted to remove all corrosion and existing coatings. After applying the zinc-aluminum alloy coating, an acrylic coating was applied as a finish coating and sealer.

The EAA-modified thermoplastic polyolefin powder coating (hereafter referred to simply as the "polyolefin coating") was applied to the support legs of a steel above-ground water-storage tank next to the $82^{\text {nd }}$ Airborne Division Headquarters building. Grit blasting was performed prior to flame-spraying the polyolefin coating, to remove all surface contaminates and old coatings and to provide a surface profile to promote adhesion.

Steel panels measuring $6 \times 12$ in. were prepared, using the same surface preparation and coatings application as the tanks, and they were mounted on a test rack for outdoor exposure testing and evaluation. Site inspections were conducted to evaluate coating performance on both the exposure panels and the tanks themselves. In addition, select panels underwent further laboratory analysis.

\subsection{Metrics}

The metrics used to assess the performance of the demonstrated systems were as follows:

1. Ease of application was determined for both the metallizing and flame spraying of the polyolefin coating, including surface preparation requirements. Surface cleanliness, grit-blasted profiles of the steel, and thicknesses of the applied coatings were measured during the demonstration phase. Overall ease of application was determined by observation of the entire process.

2. Coating effectiveness was determined for corrosion prevention and control on a steel structure. This assessment was accomplished by inspecting the applied coatings on the steel tank structures after a time period of exposure to the elements. Performance was also assessed using steel test 
panels that were coated with the same coatings as on the tanks and then mounted on an atmospheric exposure test rack. A cut line down to bare steel was purposely scribed in the test panels when first mounted on the rack. Visual corrosion on the panel and along and away from the scribe mark (called rust creepage) was used to assess the ability of the coatings for corrosion prevention of the coated steel.

3. Cost benefits were assessed on the two different coating system compared to a conventional wet-applied, high-performance coating system. This assessment was accomplished by calculating and comparing the costs per square foot for applying the coatings to the steel structures used in the demonstration. A Project Return on Investment (ROI) was performed using methods prescribed by Office of Management and Budget (OMB) Circular, Guidelines and Discount Rates for Benefit-Cost Analysis of Federal Programs (OMB 1992).

The following standards were used to execute this demonstration and to assess the performance of the demonstrated coating systems:

- SSPC-SP5 (NACE No. 1) "White Metal Blast Cleaning" was the required level of surface preparation for all surfaces of both the heating plant's fuel tank and the elevated water-storage tank's legs.

- ASTM D1014 "Standard Practice for Exterior Exposure Tests of Paints and Coatings on Metal Substrates" was used in the preparation and coating of all test panels.

- ASTM D1654 "Standard Test Method for Evaluation of Painted or Coated Specimens Subjected to Corrosive Environments," Procedure A was used in the evaluation of the scribed coating test panels.

- The flame-sprayed polyolefin coating was required to be free of pinholes when tested with a low voltage $(67.5 \mathrm{~V})$, wet sponge holiday detector.

- ASTM D4417 "Standard Test Methods for Field Measurement of Surface Profile of Blast Cleaned Steel" was used to measure the blast surface profile.

- ASTM D4541 "Standard Test Method for Pull-Off Strength of Coatings Using Portable Testers" was used in the preparation and coating of all test panels.

- Average adhesion not less than 750 psi was required for the applied zinc-aluminum alloy, with no single adhesion measurement less than $80 \%$ of the specified minimum average adhesion. 
- The flame-sprayed polyolefin coating was required to have a minimum adhesion to steel of $1000 \mathrm{psi}$, when measured at no more than four locations on each column.

- ASTM D7091 "Standard Practice for Nondestructive Measurement of Dry Film Thickness of Nonmagnetic Coatings Applied to Ferrous Metals and Nonmagnetic, Nonconductive Coatings Applied to Non-Ferrous Metals" was used to measure coating thickness for both the zinc-aluminum and polyolefin coatings.

- For the zinc-aluminum coating, a minimum average thickness of 6 mil was required for the completed system with the thickness at any one spot not be less than 5 mil.

- The flame-sprayed polyolefin coating, an average thickness of 15 mil was required, with the thickness at any one spot not less than 12 mil. 


\section{Technology Demonstration}

\subsection{Technology overview}

\subsubsection{Metallized coating}

Thermal spraying, also known as metallizing ${ }^{*}$ is a group of processes wherein feedstock metals are heated and then propelled as individual particles or liquid droplets onto a surface. The thermal spray gun generates the necessary heat by using combustible gases or an electric arc. As the materials are heated, they are changed to molten state and are confined and accelerated by a compressed gas stream to the substrate. The particles strike the substrate, flatten, and form thin platelets (splats) that conform and adhere to the irregularities of the prepared substrate and to each other. As the sprayed particles impinge upon the surface, the particles cool and then build into a laminar structure to form the thermal-spray coating.

The coating that is formed is not homogenous, and it typically contains a certain degree of porosity; also, in the case of sprayed metals, the coating will contain oxides of the metal. Feedstock material may be any substance that can be melted, including metals, metallic compounds, cements, oxides, glasses, and polymers. Feedstock materials can be sprayed as powders, wires, or rods. The bond between the substrate and the coating may be mechanical, chemical, metallurgical, or a combination of these. The properties of the applied coating are dependent on the feedstock material, the thermal-spray process and application parameters, and the post-treatment of the applied coating.

An $85 \%$ zinc and $15 \%$ aluminum alloy was selected for this demonstration. (Note that the 85/15 designation is a weight ratio, and the metals are essentially in a 50/50 ratio by volume.) Fort Bragg personnel identified several above-ground steel fuel-storage tanks as candidate facilities for the application of the zinc-aluminum alloy coating. The $33.5 \mathrm{ft}$ diameter and $34 \mathrm{ft} \mathrm{high} \mathrm{steel} \mathrm{fuel-storage} \mathrm{tank} \mathrm{shown} \mathrm{in} \mathrm{Figure} 1$ was selected for the metallizing demonstration.

\footnotetext{
*Also sometimes spelled as "metalizing."
} 
Figure 1. Heating plant fuel tank for application of the zinc-aluminum coating.

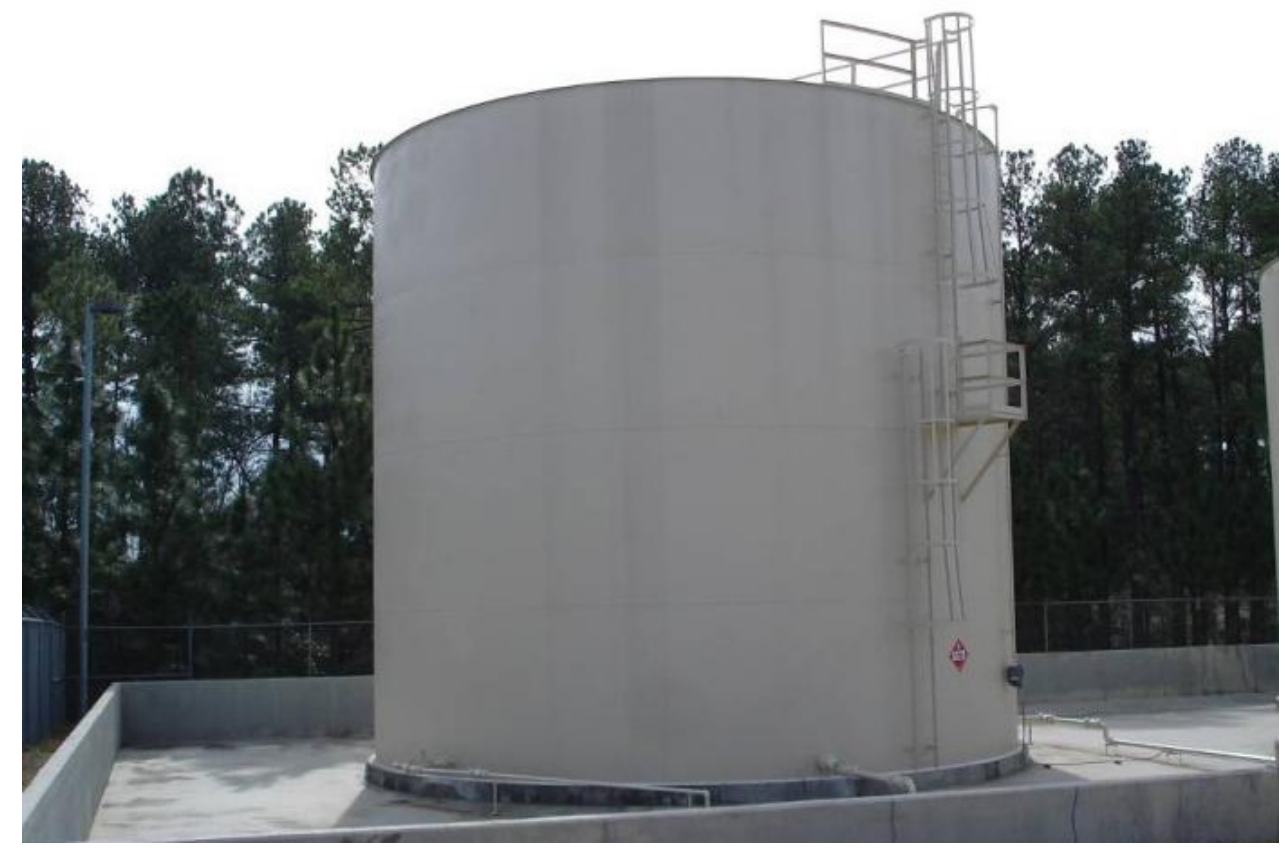

\subsubsection{Thermoplastic polymer coating (flame spray)}

Similar to the metallizing process described above, thermoplastic polymers can be melted and propelled onto a prepared metal surface to form a polymer coating. An EAA-modified polyolefin powder was selected to be flame-sprayed onto a steel surface to demonstrate this type of thermal coating process.

The flame-sprayed polyolefin powder coating was applied on approximately $625 \mathrm{sq} \mathrm{ft}$ of the potable water tank's support legs, a tank that supplies the $82^{\text {nd }}$ Airborne Division at Fort Bragg. Each leg's diameter is $2.5 \mathrm{ft}$, and four legs were coated to a height of $20 \mathrm{ft}$ to make the $625 \mathrm{sq} \mathrm{ft}$ total area of application. Application of the powder coating requires abrasive blasting of the substrate to remove original coatings and contaminants from the surface as well as to provide an anchor profile for good adhesion. The elevated water tank and support legs are shown in Figure 2. 
Figure 2. Elevated water-storage tank (left) with close-up (right) showing the support legs on which the polyolefin powder coating was to be applied.
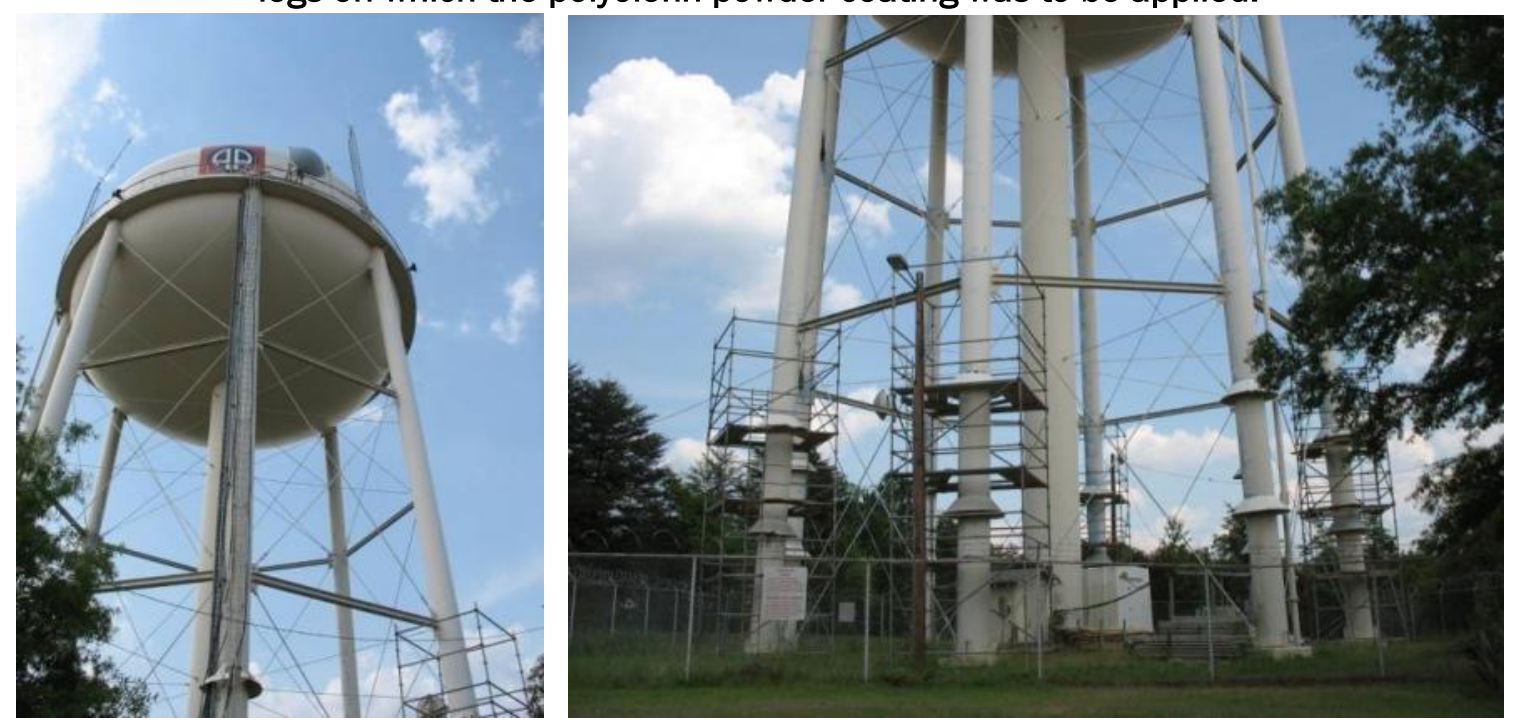

\subsubsection{Material specifications}

\subsubsection{Abrasive blast}

- Material description: "Blackblast," Grade 20-40*

- Surface quality requirement: SSPC-SP5 (NACE 1), white metal

- Surface profile requirement: 2-4 mils (0.002-0.004 in.)

\subsubsection{Zinc-aluminum alloy metallizing}

- Application machine description: "Bridgemaster"

- Material description: 85/15 zinc/aluminum alloy, $1 / 8$ in. wire (technical data sheet in Appendix A) ${ }^{*}$

- Coating thickness requirement: 6 mils (o.006 in.), average (minimum allowable, 5 mils [0.005 in.])

- Average coating adhesion requirement: 750 psi (minimum allowable, $600 \mathrm{psi})$

\footnotetext{
* Opta Minerals, Inc., headquartered in Waterdown, Ontario, Canada.

† TMS Metalizing Systems, Ltd. of Bremerton, Washington, USA.

‡ The Platt Brothers and Company of Waterbury, Connecticut, USA.
} 


\subsubsection{Top coat}

- Material description: SHER-CRYLTM HPA, single component, high performance, waterborne acrylic, FED STD 595B Color No. 23617 (semigloss); ${ }^{*}$ material technical data sheet in Appendix B

- Dry film thickness (DFT) coating requirement: 25 mils-4 miles (0.0025 in.-0.004 in.)

\subsubsection{Flame-sprayed EAA-modified polyolefin coating}

- Material description: EAA-modified polyolefin powder (technical data sheet in Appendix C) ${ }^{\dagger}$

- Application equipment description: Flame spray unit (legacy unit, no longer in production)

- Coating thickness requirement: 15 mils (0.015 in.) average; 0.012 in. minimum

\subsection{Coating application}

\subsubsection{Heating plant fuel tank}

\subsubsection{Surface preparation of steel heating plant tank}

Work began on the heating plant's tank with the erection of scaffolding and a tarp enclosure around the tank for containment of the grit blasting and coating processes (Figure 3 and Figure 4). Proper surface profile is essential for yielding the required metalized coating adhesion to the tank substrate. Accordingly, the tank surface was visually inspected for SSPC $\mathrm{SP} 5$ (white metal) continuously, and profile measurements were conducted every 100 square feet to ensure proper surface preparation (cleanliness and profile depth) had been achieved. The profile was measured with replica tape according to ASTM D4417, using a test kit with replica tape. ${ }^{*}$ Measured profile depth typically ranged from 2-4 mil. Surfaces that did not meet SSPC SP 5 requirements after inspection were reblasted and reinspected until compliance was achieved.

\footnotetext{
* Sherwin Williams Company, headquartered in Cleveland, Ohio, USA.

† PPA 571, developed by Plascoat, with U.S. distributor in Virginia Beach, Virginia.

‡ Test kit with Press-O-Film X-Coarse tape by Textex of Newark, Delaware, USA.
} 
Figure 3. Heating plant's fuel tank with containment installed (background).

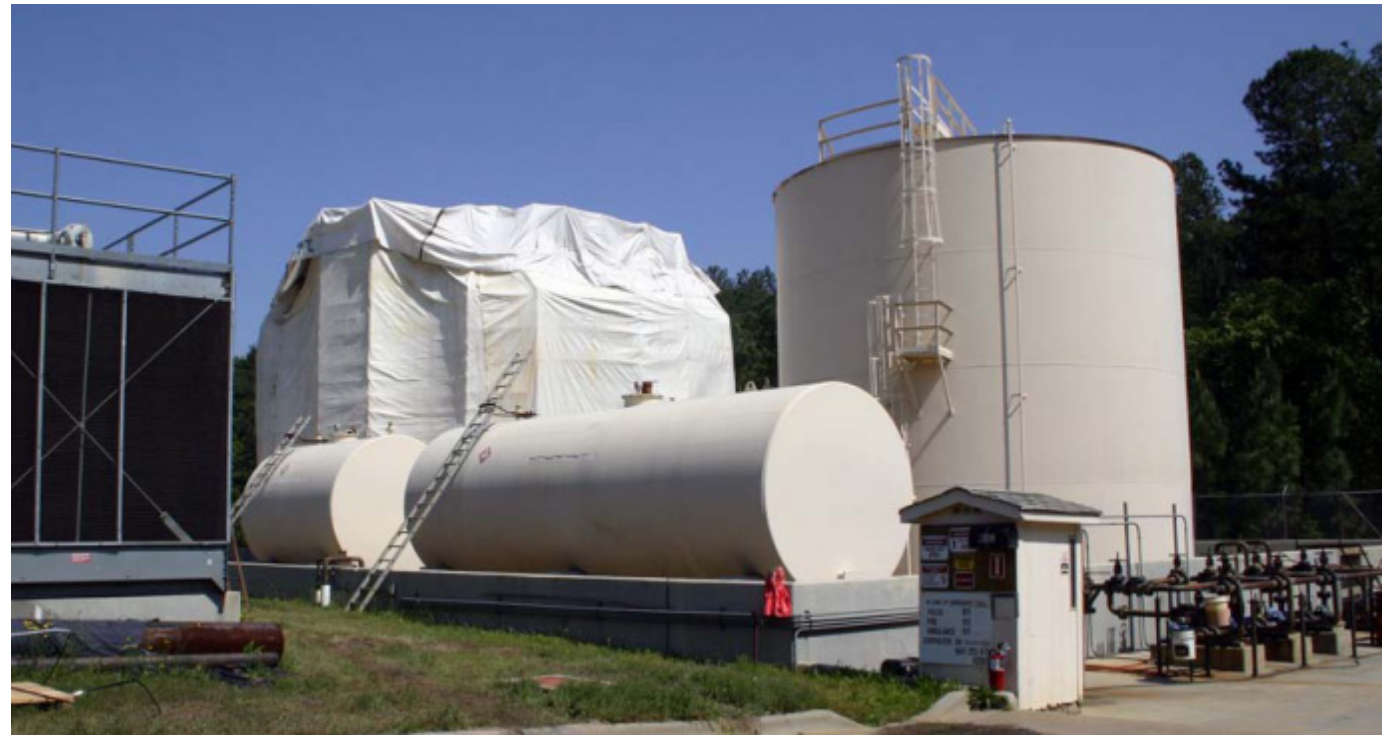

Figure 4. Inside of scaffolding and tarp enclosure around the heating plant's tank.

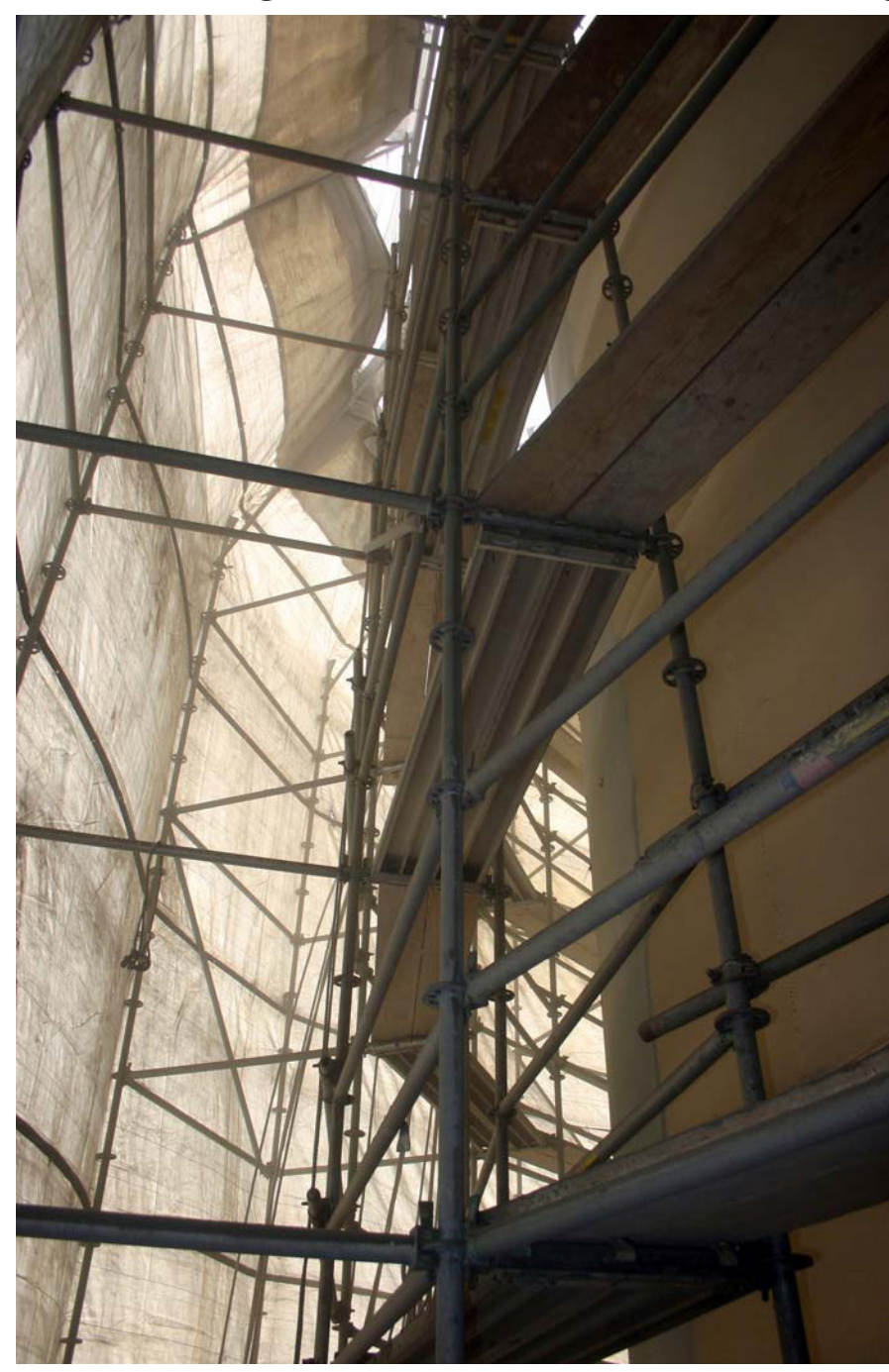




\subsubsection{Application of zinc-aluminum alloy}

After proper surface preparation was completed, 85\%/15\% zinc-aluminum alloy was arc-sprayed on the surface of the heating plant's tank, as shown in Figure 5. Abrasive blasting was coordinated with arc-spraying so that no more than 8 hours had expired between the two processes to ensure optimum adhesion of the metalizing coat to the prepared substrate. The arcspray coating was applied to achieve the required thickness by using at least two half-lapped passes at right angles.

Metallized coating thickness was measured during application per ASTM D7091 to ensure compliance with project requirements (average thickness of 6.0 mils with no less than 5.0 mils at any measurement site). ${ }^{*}$ For measurement purposes, the tank surface was divided into areas of approximately $100 \mathrm{sq} \mathrm{ft}$. The coating thickness was measured at six locations within each designated $100 \mathrm{sq} \mathrm{ft}$ area. Final thickness was obtained by taking the average of three readings within a 4 in. square at each of the six locations. Average coating thickness ranged from 7.0-9.0 mil over the entire tank. The minimum thickness measured was $6.1 \mathrm{mil}$, and the maximum thickness measured was 15.0 mil.

Figure 5. Thermal arc spray application of $85 / 15$ alloy.

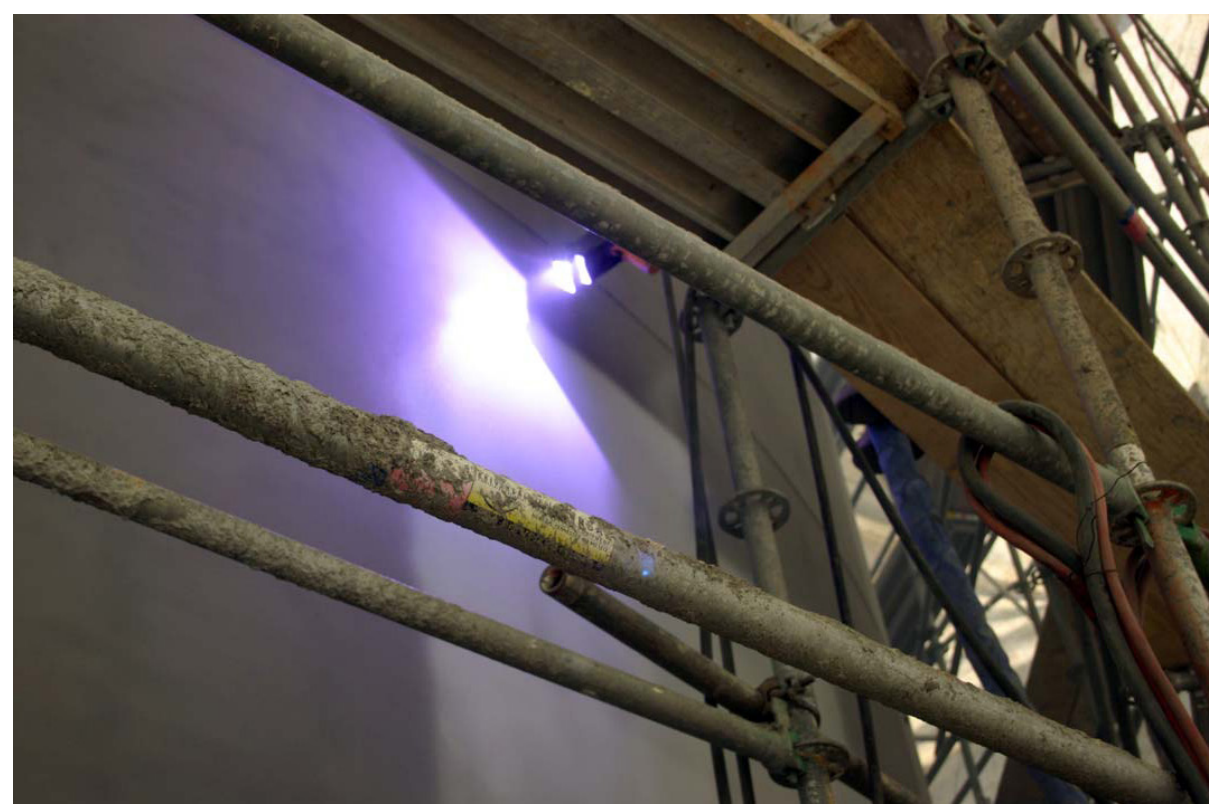

* MicroTest FM6 gauge by ElektroPhysik, headquartered in Cologne, Germany. 
Metalized coating adhesion was measured per ASTM D4541 at three locations on the tank, using a hydraulic pull tester. ${ }^{*}$ All three adhesion measurements (dolly breakaway) exceeded $750 \mathrm{psi}$ (required minimum $600 \mathrm{psi}$ at any measurement site). In addition, coating adhesion was measured on three steel test coupons prepared identically to the tank surface. Measured adhesion values (breakaway) on the three test panels were 975 psi, $967 \mathrm{psi}$, and 940 psi.

The metalized coating was then coated with the high-performance, waterborne acrylic in accordance with the manufacturer's specifications (Appendix B). Total coating thickness (85/15 plus topcoat) was measured by gauge for compliance with project requirements. Total thickness measurements indicated that the topcoat had been applied in accordance with the manufacturer's recommended specifications (2.5-4.0 mil over metalized coating).

\subsubsection{Elevated steel water tank legs}

\subsubsection{Surface preparation of elevated steel water tank legs}

The polyolefin coating was applied to approximately $625 \mathrm{sq} \mathrm{ft}$ of surface area that was distributed over four of the eight $2.5 \mathrm{ft}$. diameter legs of the elevated water tank. The selected legs to be coated were first fitted with scaffold and tarp to contain the abrasive blast process, as shown in Figure 6 and Figure 7. As with the heating plant's fuel tank, the surface of the steel was prepared by grit blasting to remove the existing coating and other contaminants as well as to provide an aggressive surface profile for enhanced adhesion. The blasted surfaces were inspected for compliance with the requirements of SSPC SP 5 (white metal). Surfaces that did not meet SSPC SP 5 requirements after inspection were reblasted and reinspected until compliance was achieved. Surface profiles were measured and averaged at multiple sites on each leg with a test kit using replica tape and associated micrometer to verify that the required 2-4 mil anchor profile had been established.

\footnotetext{
* Elcometer 108 Hydraulic Adhesion Tester, with U.S. distributors in Rochester Hills, Michigan, and Houston, Texas.
} 
Figure 6. Water tower leg with containment being installed prior to abrasive blasting.

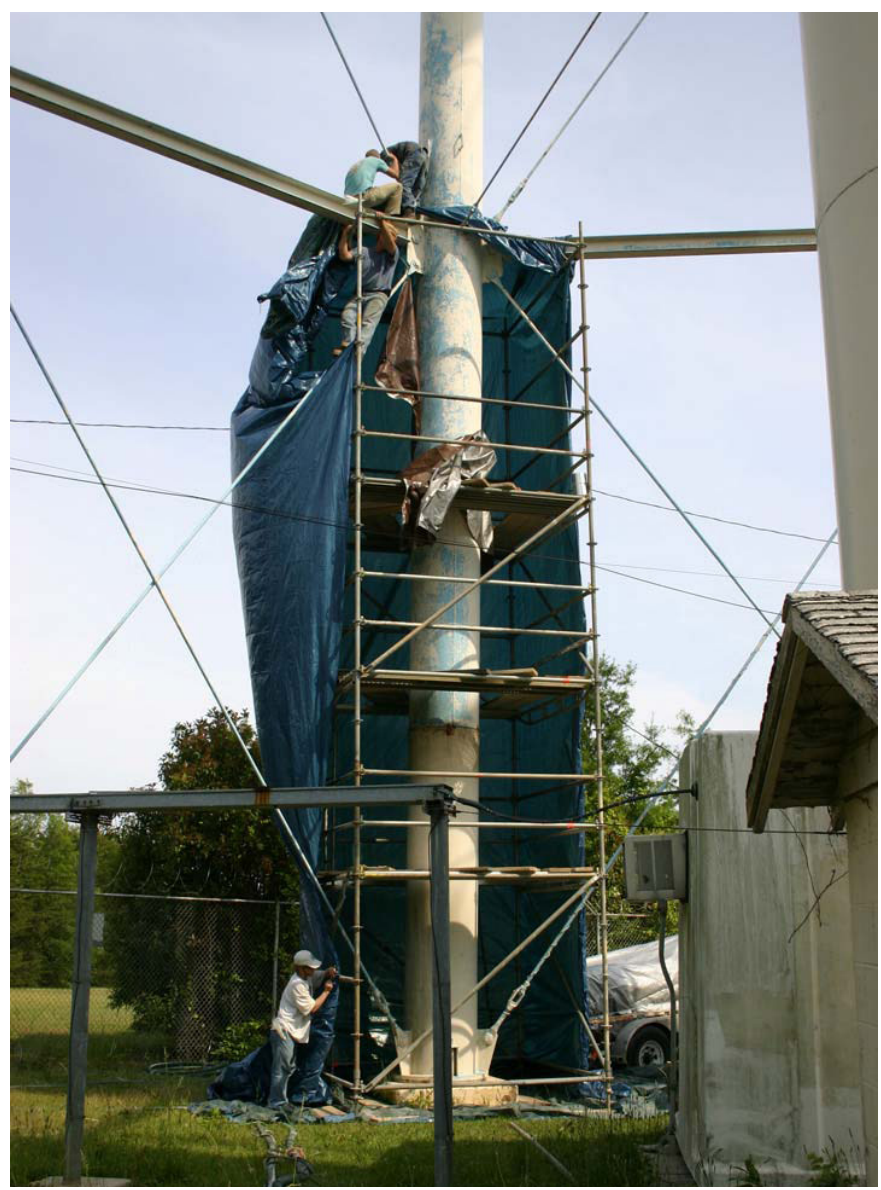

Figure 7. Water tower leg containment during abrasive blast.

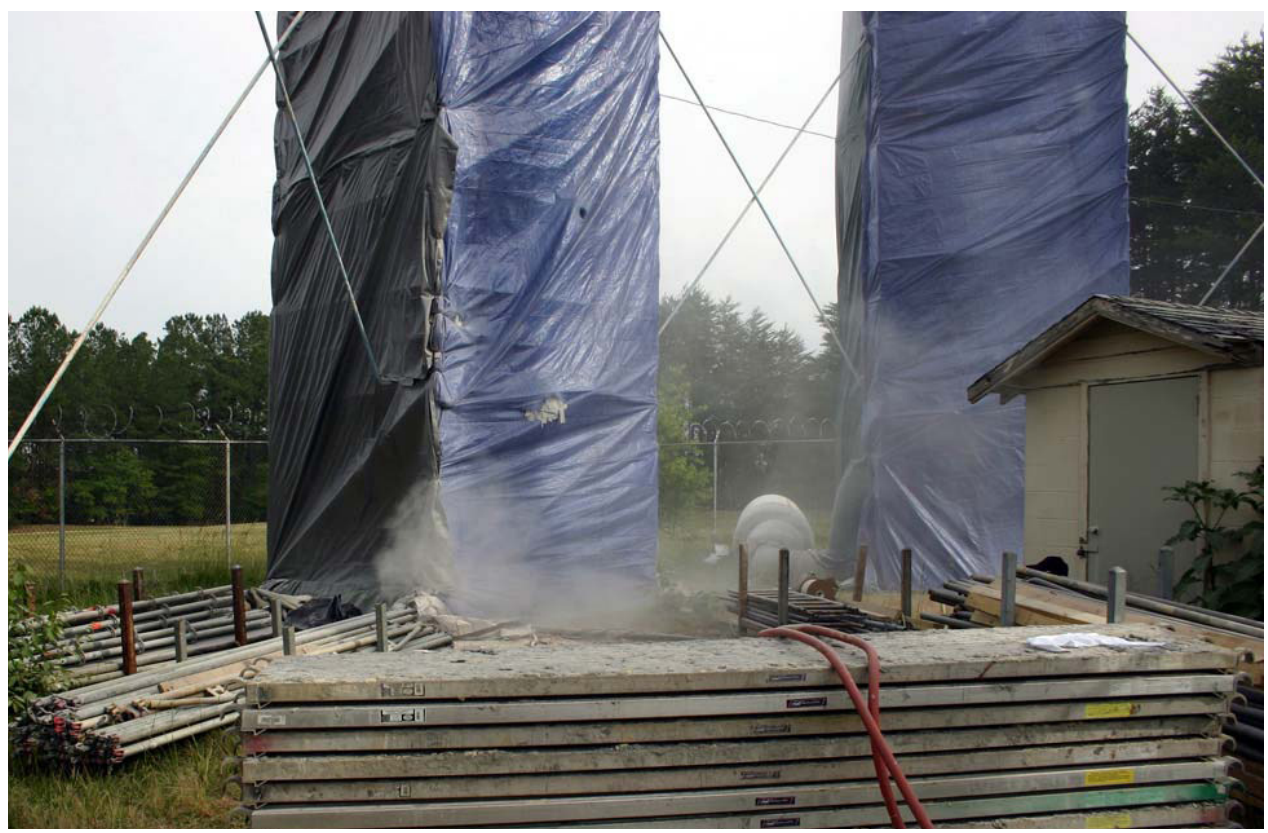




\subsubsection{Flame spraying of polyolefin powder coating}

Flame spraying of the polyolefin powder was initiated at the conclusion of the abrasive blasting activity for each tank leg. The coating material ${ }^{*}$ consisted of thermoplastic polymers, pigments, and other additives which were melt-blended by the manufacturer prior to grinding into a powder format for application through a propane gas flame. Table 1 lists the property requirements of the polyolefin powder coating material.

Table 1. Polyolefin coating requirements.

\begin{tabular}{|l|l|l|l|}
\hline \multirow{2}{*}{} & \multicolumn{3}{|c|}{ Property } \\
\cline { 2 - 4 } & $\begin{array}{l}\text { Melt Index } \\
\left(@ 190^{\circ} \mathrm{C}, 2.16 \mathrm{Kg} \mathrm{Load}\right)- \\
\mathrm{g} / 10 \text { Minutes }\end{array}$ & $\begin{array}{l}\text { Density } \\
-\mathrm{g} / \mathrm{cm}^{3}-\end{array}$ & $\begin{array}{l}\text { Hardness } \\
- \text { Shore D - }\end{array}$ \\
\hline Requirement & $3 \pm 1$ & $\begin{array}{l}0.940 \text { to } \\
0.970\end{array}$ & $55 \pm 2$ \\
\hline Per ASTM Standard & $\mathrm{D} 1238 *$ & $\mathrm{D} 792 * *$ & $\mathrm{D} 2240 * * *$ \\
\hline
\end{tabular}

* "Standard Test Method for Melt Flow Rates of Thermoplastics by Extrusion Plastometer."

* * "Standard Test Methods for Density and Specific Gravity (Relative Density) of Plastics by Displacement."

*** "Standard Test Method for Rubber Property-Durometer Hardness."

Prior to applying the coating, the metal substrate was preheated to $150^{\circ} \mathrm{F}$ $\left(65^{\circ} \mathrm{C}\right)$ to promote adhesion and flow-out of the melted thermoplastic material. A propane torch was used to heat and maintain substrate temperature ahead of the coating application. Surface temperature was measured and monitored by using a digital handheld infrared (IR) thermometer. The powder was dispensed from a storage hopper on the flame spray machine cabinet. Powder is drawn from the conical hopper using a venturi nozzle at the hopper base using compressed air. The air and powder mixture was propelled through the application gun's flame to melt the thermoplastic material for spraying onto the substrate. Application activities are shown in Figure 8-Figure 10. 
Figure 8. Application of EAA-modified polyolefin powder coating (lighter color) with flame spray.

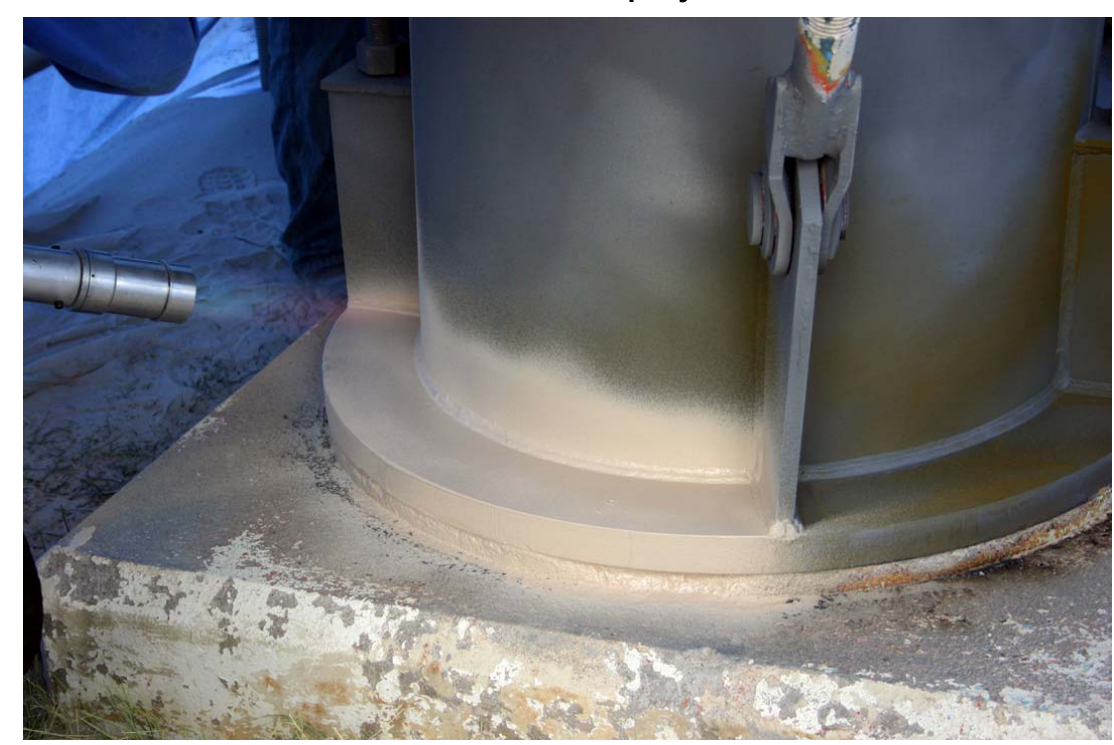

Figure 9. Polyolefin coating (lighter color) applied on water tower leg.

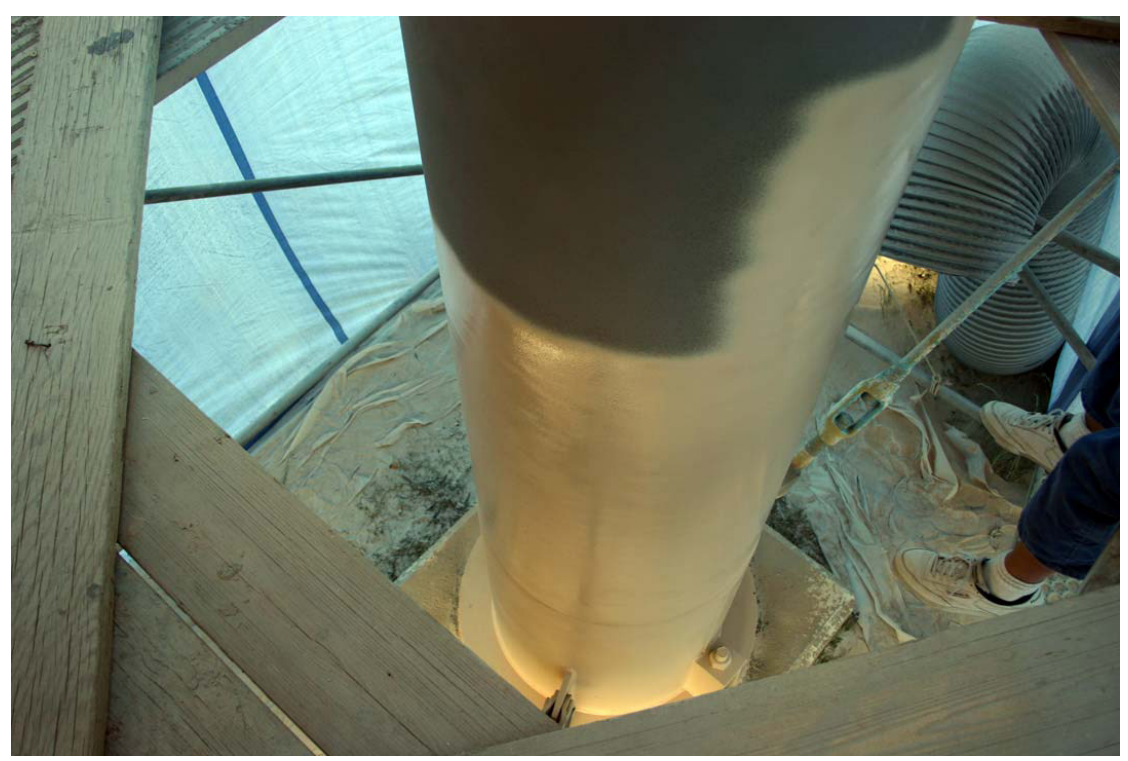


Figure 10. Polyolefin powder being added through a sifter to the hopper of a flamespray unit to remove any large particles.

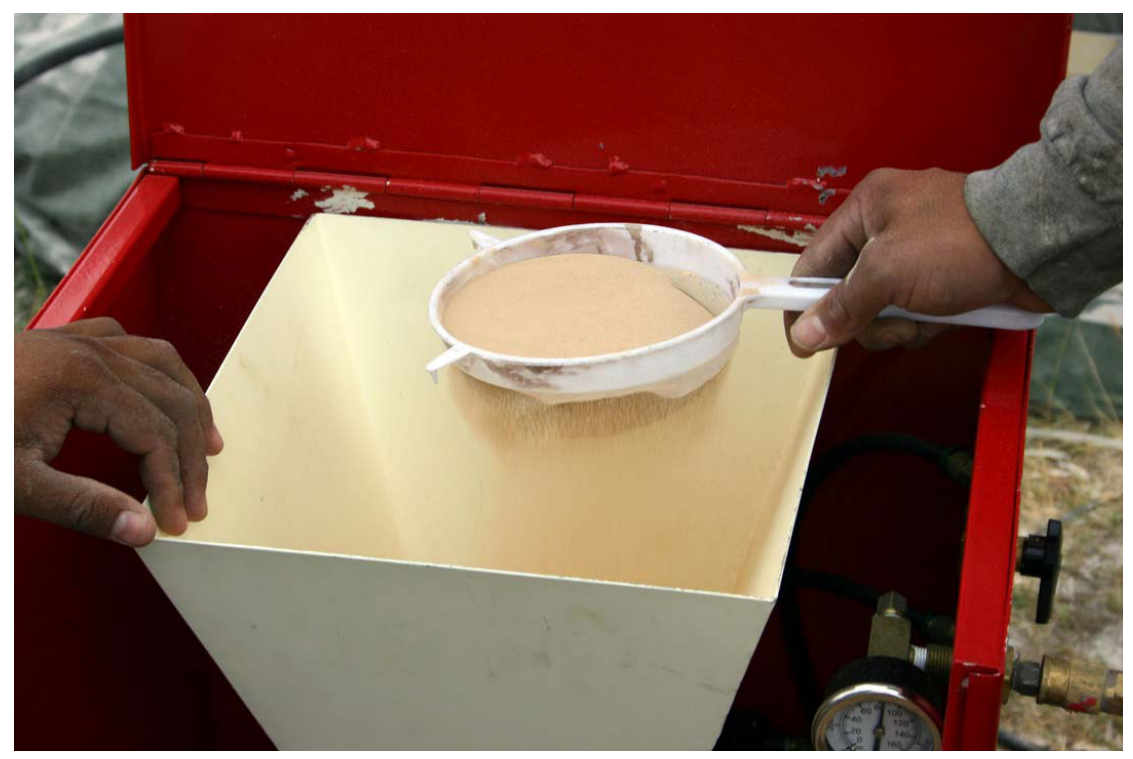

Flame spraying was started at grade level and proceeded upward and around the support leg by using multiple overlapped passes at right angles to achieve desired thickness and to maintain thickness uniformity. Four water tank legs were blasted with abrasive and coated to a height of $20 \mathrm{ft}$ over a period of four days. Coating thickness was measured by using a digital instrument ${ }^{*}$ at regular intervals by averaging multiple readings in a small area at each measurement site. Coating thickness averaged between 13 mil and 20 mil.

Coating adhesion measurements were taken per ASTM D 4541 with the Elcometer 108 instrument at three randomly selected sites. The three break-away readings were 1864 psi, 1786 psi, and 1846 psi. Minimum requirement was 1,000 psi. The coating of flame-sprayed polyolefin coating was free of pinholes when tested with a low-voltage (67.5 volts), wet sponge holiday detector.

\subsubsection{Test panels}

Twelve mild steel-coating test panels ( 6 x $12 \times 0.125$ in.) were prepared for exterior exposure per ASTM D 1014. Six panels were prepared using the same surface preparation, metallizing, and top coating as was used for the heating plant's fuel tank. Another six panels were prepared by using the

\footnotetext{
* Elcometer 456, Type II
} 
same surface preparation and flame-spray application of the polyolefin coating as used on the elevated water tank's legs.

\subsection{Performance monitoring}

Performance monitoring of the two coatings was done by using the test panels described above and by making periodic inspections of the facilities to which the coatings were applied. The coated panels were mounted 2 February 2009 on a test rack for outdoor weathering exposure located at the $82^{\text {nd }}$ Airborne Power Plant. The panels, as mounted on the rack, are shown in Figure 11.

Figure 11. Exterior exposure test panels: Polyolefin coating, bottom row from left; zinc-aluminum metallized coating sealed with acrylic topcoat - bottom row, right.

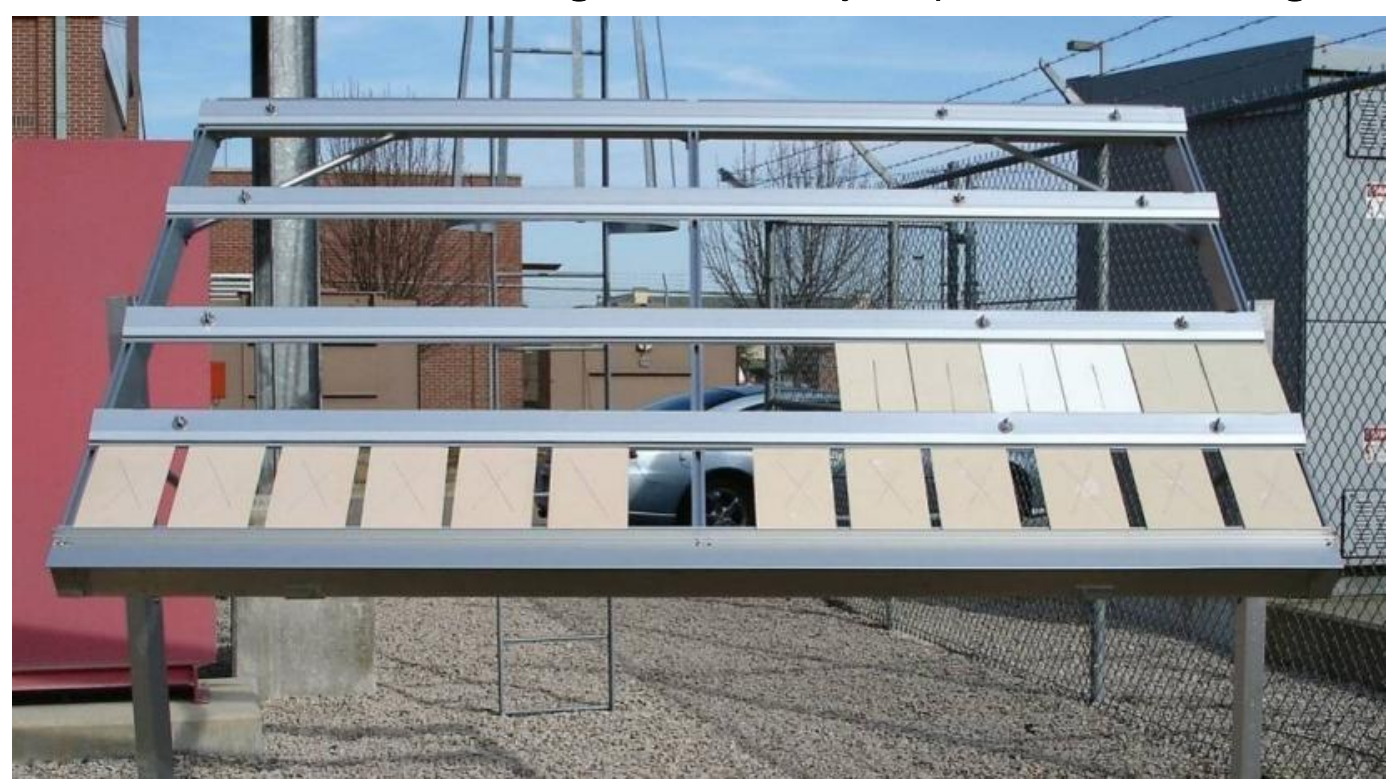




\section{Discussion}

\subsection{Results}

\subsubsection{Field inspection}

Field work on the heating plant's fuel tank and the four legs of the water tower began on 21 April 212008 and was successfully completed on 14 May 2008. ERDC-CERL personnel were on site during two periods in 2008, 29 April-1 May and 13-14 May, to observe the metallizing and flame-spraying operations. The heating plant tank and water tower legs were satisfactorily coated with the subject demonstration coatings.

Following 7 years of exposure, the heating plant's fuel tank and the elevated water tank's legs were visually inspected by an ERDC-CERL engineer on 06 May 2015. The mounted exposure panels were also inspected on this date, after which randomly selected panels were removed for further evaluation by the ERDC-CERL paint laboratory.

A thorough visual inspection of the heating plant's fuel tank showed that the 85/15 zinc-aluminum coating was still providing corrosion protection after 7 years exposure. Particular attention was paid to areas of penetrations and weld filets. No visible rusting was observed. Figure 12 shows the heating plant's fuel tank, as inspected. 
Figure 12. Heating plant's fuel tank, as inspected on 6 May 2015. The visible, dark areas are dirt and algae staining.

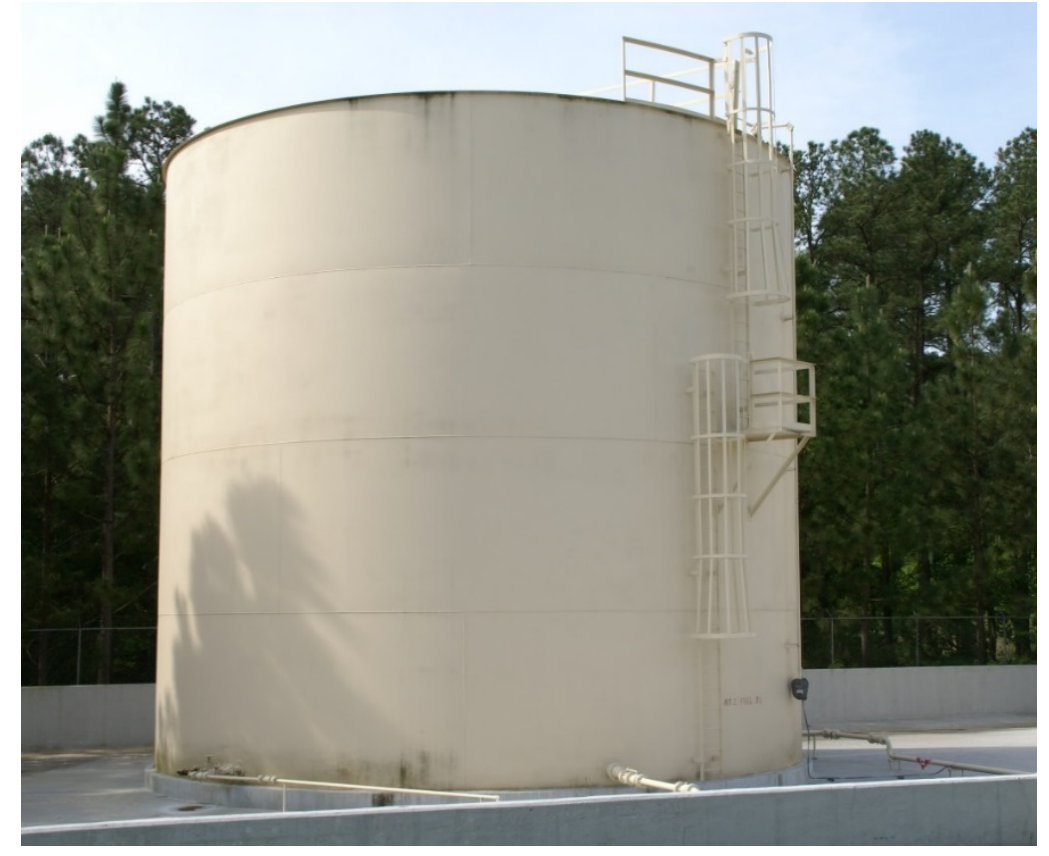

A thorough visual inspection was also performed on the elevated water tower tank's legs, showing the polyolefin coating was still providing corrosion protection after seven years exposure. Figure 13 shows one of the legs, as inspected.

Visual inspection of the exposure panels on the test rack also indicated that the coatings were providing excellent corrosion protection to the steel. Randomly selected panels were brought back to ERDC-CERL and subjected to further evaluation in the laboratory, as described in section 3.1.2. 
Figure 13. One of the elevated water tower's legs finished with the flame-sprayed polyolefin coating, as inspected on 6 May 2015.

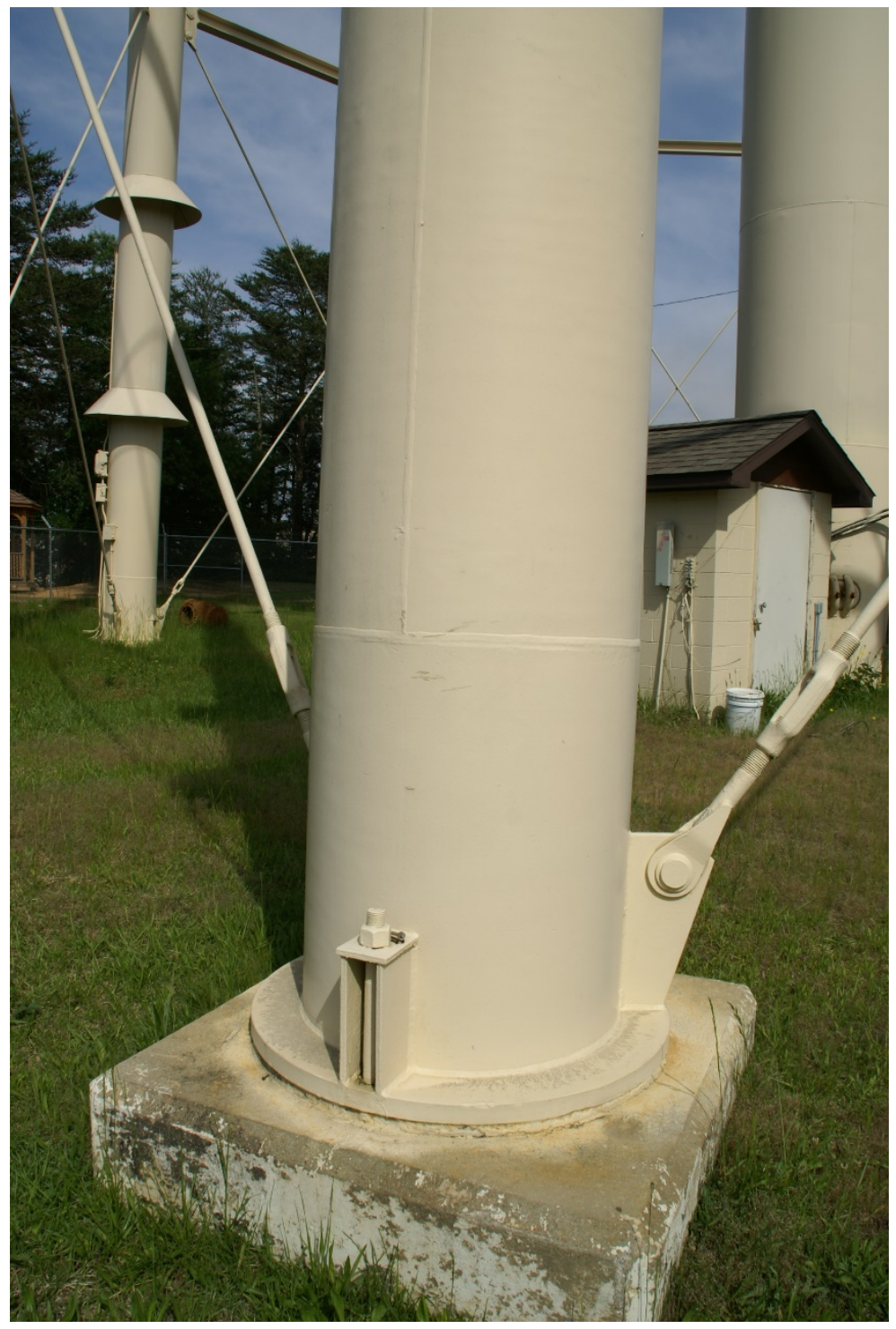

\subsubsection{Laboratory analysis}

Of the panels selected for further laboratory analysis, four were metallized with the 85/15 zinc-aluminum coating and acrylic topcoat, and three were coated with the thermoplastic polyolefin coating system (panel designation TPC). Table 2 lists the results of coating thickness measurements, gloss measurements, and rust creepage per ASTM D1654. 
Table 2. Results of laboratory analysis of exposure panels.

\begin{tabular}{|l|c|c|c|}
\hline Panel Designation & $\begin{array}{l}\text { Thickness, } \\
\text { Average (mil) }\end{array}$ & $\begin{array}{l}\text { Gloss, Average } \\
\text { (specular gloss per } \\
\text { ASTM D523) }\end{array}$ & $\begin{array}{l}\text { Rust Creep } \\
\text { from Scribe } \\
\text { (Grade per ASTM } \\
\text { D1654 Procedure A) }\end{array}$ \\
\hline 85/15- 07 & 7.5 & 2.5 & 10 \\
\hline $85 / 15-09$ & 10.2 & 2.1 & 10 \\
\hline $85 / 15-10$ & 13.0 & 2.2 & 10 \\
\hline $85 / 15-12$ & 16.2 & 5.0 & 9 \\
\hline TPC- 13 & 17.8 & 3.1 & 10 \\
\hline TPC- 15 & 17.2 & 9.5 & 8 \\
\hline TPC- 17 & & & 10 \\
\hline
\end{tabular}

The rust creep results per ASTM D1654 are a very good indicator of the coating performance. (Note that per ASTM D1654, a numerical rating of 10 is the highest rating, where rust creepage is at zero. At the other end of the rating scale, a numerical rating of o means that the measured rust creepage was greater than $16 \mathrm{~mm}$.) The zinc-aluminum coating system is still providing excellent corrosion protection to the base steel even after seven years of exposure to the elements. The polyolefin coating system is still providing very good to excellent corrosion protection.

\subsection{Lessons learned}

While both the metallized and polyolefin coatings were applied to specification, there were some issues encountered with the contractor achieving minimum surface preparation and required profiles, and with coating thicknesses. The contractor had to go back and reblast areas to achieve minimum surface preparation (white metal) and/or surface profile requirements. The contractor likewise had to go back and apply additional coating to meet minimum thickness especially for the zinc-aluminum metallizing. The following insights are presented for further consideration. 


\subsubsection{Application issues}

Neither the metallizing nor flame-spraying operations lend themselves to rapid application of the coatings. The metallizing was done with a handheld gun that applies a small pattern of material. As such, it is easy for the applicator to produce significantly different thicknesses within a small areas. Measurements were therefore taken on virtually every square foot. For this purpose, single measurements were taken (not triplicate as required by ASTM D7091). Wherever the single measurement was below the contract minimum, additional measurements were taken to accurately define the deficient area. New-generation, dual-wire, high-deposition, thermal spray equipment now allows for larger areas of freshly abrasiveblasted surfaces to be coated within the prescribed time limits, whereas older single-wire application rates allowed significantly less area to be coated.

Both coatings must be applied over blasted, white-metal surfaces. The blasting operation can prepare more surface area than the coating applicators can cover in a given amount of time, raising the possibility that prepared surfaces may flash rust if blast operations outrun the coating applicators by too great a margin. Therefore, coating and blasting operations must be well coordinated to prevent causing excessive rework.

\subsubsection{Operational issues}

The EAA-modified polyolefin powder coating is not readily available in the United States, and the color selection is limited. In addition, the powder is expensive, and obtaining nonstandard colors requires minimum purchases that may exceed the amount needed for small- or moderate-size projects. Several boxes of powder went unused for this project. 


\section{Economic Summary}

\subsection{Costs and assumptions}

Total project costs for this project were $\$ 780,000$, as shown in Table 3. An estimated breakdown of costs for the field demonstration (contract) portion of the total costs is shown in Table 4.

Table 3. Breakdown of total project costs for the demonstration of long-life thermal spray coatings.

\begin{tabular}{|l|r|}
\hline Description & Amount, \$K \\
\hline Labor & 242 \\
\hline Contracts & 483 \\
\hline Travel & 25 \\
\hline Reporting & 20 \\
\hline Air Force and Navy participation & 10 \\
\hline Total & 780 \\
\hline
\end{tabular}

Table 4. Long-life thermal spray coatings project costs for the contracted field work.

\begin{tabular}{|c|l|r|}
\hline Item & \multicolumn{1}{|c|}{ Description } & Amount, \$K \\
\hline 1 & Labor for project management and execution & 63 \\
\hline 2 & Travel for project management & 10 \\
\hline 3 & Abrasive blasting of fuel tank & 175 \\
\hline 4 & Abrasive blasting of water tank legs & 91 \\
\hline 5 & Arc spraying of fuel tank & 83 \\
\hline 6 & Sealing fuel tank & 21 \\
\hline 7 & Flame spraying water tank legs & 21 \\
\hline 8 & Cost for EAA-modified polyolefin powder & 19 \\
\hline & Total & 483 \\
\hline
\end{tabular}

Not including ladders and piping fixtures, the heating plant's fuel tank has roughly $4,460 \mathrm{sq} f t$ of surface area. Given costs for surface preparation, materials, and labor for arc spraying per this demonstration project, the total cost of metallizing comes to approximately $\$ 58$ per square foot. Given that $625 \mathrm{sq} \mathrm{ft}$ of the water tower's legs were prepared and coated with the flame-sprayed polyolefin system, the total cost of flame spraying the polyolefin powder coating comes to approximately $\$ 210$ per square foot. 
The $\$ 58$ cost per square foot for metallizing, as calculated under this demonstration, is considered to be slightly higher than is typical for a similar project. While many variables can go into establishing actual costs, a $\$ 45$ per square foot cost is considered by ERDC-CERL researchers to be a more reasonable estimate for the work performed (approximately a $25 \%$ reduction to account for contractor inexperience and having to redo grit blasting to achieve the minimum surface profile and cleanliness and applying additional metallizing to achieve required coating thickness). Therefore, $\$ 45$ per square foot is used in subsequent analyses and calculations.

Given that metallizing provides a very high degree of corrosion protection at a significantly lower cost over the flame-sprayed polyolefin coating, no further economic analysis was considered at this time for the polyolefin coating system. Due to a required minimum purchase amount and much of the purchased powder material not used, the cost per square foot was artificially higher than it should be. (A demonstration project only on thermally applied thermoplastic coatings should be considered in the future.)

\subsubsection{General assumptions}

Each Army or other DoD installation can have dozens of steel tanks (e.g., water and fuel) that could be candidates for the metallizing technology. For cost comparisons, assume 50 steel tanks of the type and size used in this demonstration will be metallized at the rate of 10 per year, and each tank has $4,460 \mathrm{sq} f \mathrm{ft}$ of surface area to be coated. The total investment required for this demonstration project was $\$ 780,000$ (as itemized in Table 3 above and entered in top line of Table 5 below).

\subsubsection{Alternative 1 (baseline scenario)}

Over a 5-year period (starting in year 10 to reflect present-day conditions), 10 steel fuel tanks will be coated each year with a high-performance organic coating system typically used in a corrosive environment. Using R.S. Means data (Waier 2011), the total cost of applying a high-performance coating system is $\$ 19$ per square foot. At $4,460 \mathrm{sq} f \mathrm{ft}$ per tank, coating costs total $\$ 847,400$ for 10 tanks per year. Starting in year 15 ( 5 years after coating), each group of 10 tanks will require repair and maintenance at $\$ 10,000$ per tank for a per-year maintenance and repair cost of $\$ 100,000$ for 10 tanks. The repair and maintenance cycle continues through year 25, 
when each group of 10 tanks will need to be completely repainted. The repair and maintenance cycle starts up again 5 years later. These costs are shown in the Baseline Costs in Column B of Table 5.

Some already-existing tanks that had been coated $15^{+}$years before the start of this analysis (in year 10) are expected to begin leaking by years 10 through 14 . This leakage will result in a $\$ 1,450,000$ annual cost for years 10-13 due to environmental violations, environmental cleanup, and the costs for trucking in fuel (cost figure is taken from original Project Management Plan [PMP]). Leakage on some tanks will occur again in years 2529 , initiating the recoating of each group of 10 tanks in the year following the leakage. The costs associated with the leakage and cleanup are included in the Baseline Costs in years 25-29 in Table 5.

\subsubsection{Alternative 2 (demonstrated technology)}

Over a 5-year period (also starting in year 10), 10 steel fuel tanks will be metallized with the $85 / 15$ zinc-aluminum coating at a cost of $\$ 45$ per square foot. This assumption results in an annual cost per group of 10 tanks of $\$ 2,007,000$, as shown for years 11-14 in Column D (New System Costs) in Table 5. Since the Investment Required covered the cost of coating one of the ten fuel tanks, the first year costs (shown in year 10) are reduced by $\$ 200,700$. No further repair or maintenance activity is required over a 30-year period. These costs are shown in Table 5 under New System Costs.

\subsection{Projected return on investment (ROI)}

The ROI for this technology demonstration was computed using methods prescribed by Office of Management and Budget (OMB) Circular, Guidelines and Discount Rates for Benefit-Cost Analysis of Federal Programs (OMB 1992). Comparing the costs and benefits of the two alternatives, the 30-year ROI after implementing the new technology (Alternative 2) is projected to be 2.94, as shown in Table 5 . 
Table 5. Projected ROI.

\section{Return on Investment Calculation}

Investment Required

Return on Investment Ratio

Net Present Value of Costs and Benefits/Savings

$\begin{array}{r}2.94 \\ \hline 4,373,996\end{array}$

E

New System Benefits/Savings
Present Valur

Costs
Value of

\begin{tabular}{|c|c|}
\hline & 780,000 \\
\hline Percent & $294 \%$ \\
\hline $6,664,387$ & $2,290,392$ \\
\hline
\end{tabular}

New System Costs
G
Present Value of Savings
H

Total Present Value

\begin{tabular}{|c|c|c|c|c|c|}
\hline 1 & & & & & \\
\hline 2 & & & & & \\
\hline 3 & & & & & \\
\hline 4 & & & & & \\
\hline 5 & & & & & \\
\hline 6 & & & & & \\
\hline 7 & & & & & \\
\hline 8 & & & & & \\
\hline 9 & & & & & \\
\hline 0 & $2,297,400$ & $1,806,300$ & 918,142 & $1,167,768$ & 249,626 \\
\hline 1 & $2,297,400$ & $2,007,000$ & 953,526 & $1,091,495$ & 137,969 \\
\hline 2 & $2,297,400$ & $2,007,000$ & 891,108 & $1,020,046$ & 128,938 \\
\hline 3 & $2,297,400$ & $2,007,000$ & 832,905 & 953,421 & 120,516 \\
\hline 4 & 847,400 & $2,007,000$ & 778,315 & 328,622 & $-449,693$ \\
\hline 5 & 100,000 & & & 36,240 & 36,240 \\
\hline 16 & 100,000 & & & 33,870 & 33,870 \\
\hline 17 & 100,000 & & & 31,660 & 31,660 \\
\hline 18 & 100,000 & & & 29,590 & 29,590 \\
\hline 19 & 100,000 & & & 27,650 & 27,650 \\
\hline 20 & 100,000 & & & 25,840 & 25,840 \\
\hline 21 & 100,000 & & & 24,150 & 24,150 \\
\hline 22 & 100,000 & & & 22,570 & 22,570 \\
\hline 23 & 100,000 & & & 21,090 & 21,090 \\
\hline 24 & 100,000 & & & 19,710 & 19,710 \\
\hline 25 & $1,550,000$ & & & 285,510 & 285,510 \\
\hline 26 & $2,297,400$ & & & 395,612 & 395,612 \\
\hline 27 & $2,297,400$ & & & 369,652 & 369,652 \\
\hline 28 & $2,297,400$ & & & 345,529 & 345,529 \\
\hline 29 & $2,297,400$ & & & 323,014 & 323,014 \\
\hline 30 & 847,400 & & & 111,348 & 111,348 \\
\hline
\end{tabular}




\section{Conclusions and Recommendations}

\subsection{Conclusions}

The demonstration of the metallizing on the heating plant fuel tank and exposure test panels shows that a 85/15 zinc-aluminum coating system can provide excellent corrosion protection for steel in atmospheric exposure. Metalizing costs more than conventional organic coating systems, but it can provide a long maintenance-free life. Life-cycle costs must therefore be considered when making the final choice.

Based strictly on the results of this project, flame-spraying a polyolefin coating on a large steel structure for corrosion protection is much too costly compared to standard liquid-applied organic coating systems-\$210 per square foot versus $\$ 19$ per square foot.

\subsection{Recommendations}

\subsubsection{Applicability}

Based on the results of this project, thermally sprayed metallic coatings are recommended for wider applications. Metallizing is an often overlooked viable alternative in highly and severely corrosive environments to using liquid-applied, high-performance organic coating systems. Prospective applications include atmospheric and immersion service. In addition to the $85 / 15$ zinc-aluminum alloy, other metallic coatings are also available, such as $100 \%$ zinc, $100 \%$ aluminum, and $90 / 10$ aluminum-aluminum oxide.

While the flame-sprayed polyolefin coating system, as demonstrated under this project, showed that total costs were prohibitively high compared to conventional organic coatings and even metallizing, these polymeric coatings are still thought to have value for corrosion protection in highly corrosive environments.

It is recommended that a future demonstration project be considered for flame-sprayed polyolefin coating technology, using the latest state-of-theart materials and equipment on a structure or facility that would make best use of a thermally applied polymer coating. 


\subsubsection{Implementation}

Guidance documents are available to help determine if metallizing is the best choice for a protective coating system and to procure the metallizing system if selected for use. These documents include: Engineer Manual (EM) 1110-2-3401, Engineering and Design - Thermal Spraying: New Construction and Maintenance Proponent and Unified Facilities Guide Specification (UFGS) 0997 10.00 10, Metallic Coatings for Hydraulic Structures.

Except for certain instances such as environmental restrictions relative to volatile organics as used in most organic paint systems, the choice between metallizing and conventional paint coatings should be based on life-cycle costs. Chapter 4 in EM 1110-2-3401 covers "Thermal Spray Coating Cost and Service Life." Metallizing is often overlooked because of higher upfront costs but it may be the most economical choice on a life-cycle cost basis. A stepwise procedure is provided in Chapter 4 to the EM, to develop a life-cycle cost comparison. Table 4-1 in this EM lists "Predicted Service Life for Selected Thermal Spray Applications.”

Chapter 5 in this EM covers "Thermal Spray Coating Selection," and Table 5-3 gives "Recommended Thermal Spray Systems for Atmospheric Exposures." While this EM is focused mainly on Civil Works hydraulic structures and components, the information is also relevant to military facilities in related corrosive exposures.

UFGS 099710.0010 can be used to specify metallizing. This UFGS coordinates with the EM for the various metallic coating systems. Again, while the title suggests use for hydraulic structures, the guidance is relevant to military facilities and structures that are located in severe corrosion prone locations. 


\section{References}

ASTM D523. 2014. "Standard Test Method for Specular Gloss." West Conshohocken, PA: ASTM International.

ASTM D1014. "Standard Practice for Exterior Exposure Tests of Paints and Coatings on Metal Substrates.” West Conshohocken, PA: ASTM International.

ASTM D1654. "Standard Test Method for Evaluation of Painted or Coated Specimens Subjected to Corrosive Environments." West Conshohocken, PA: ASTM International.

ASTM D4417. "Standard Test Methods for Field Measurement of Surface Profile of Blast Cleaned Steel." West Conshohocken, PA: ASTM International.

ASTM D4541. "Standard Test Method for Pull-Off Strength of Coat-ings Using Portable Testers.” West Conshohocken, PA: ASTM International.

ASTM D7091. "Standard Practice for Nondestructive Measurement of Dry Film Thickness of Nonmagnetic Coatings Applied to Ferrous Metals and Nonmagnetic, Nonconductive Coatings Applied to Non-Ferrous Metals.” West Conshohocken, PA: ASTM International.

Engineer Manual (EM) 1110-2-3401. 29 January 1999. Engineering and Design Thermal Spraying: New Construction and Maintenance. Washington, DC: U.S. Army Corps of Engineers.

Herzberg, Eric, Amelia Kelly, and Norman O’Heara. July 2010. “The Annual Cost of Corrosion for the Department of Defense Facilities and Infrastructure, 20072008 Update.” Report\# DL907T2. Tysons, VA: LMI Consulting.

Office of Management and Budget (OMB). 1992 (with Appendix C revised annually). Guidelines and Discount Rates for Benefit-Cost Analysis of Federal Programs. OMB Circular No. A-94. Washington, DC: Office of Management and Budget.

SSPC-SP5/NACE No. 1. 1999. "White Metal Blast Cleaning.” Joint Surface Preparation Standard. Pittsburg, PA: SSPC (The Society for Protective Coatings) and Houston, TX: NACE International.

Unified Facilities Guide Specification (UFGS) Division o9 - Finishes, Section 099710.00 10. May 2009. Metallic Coatings for Hydraulic Structures. Washington, DC: Department of Defense.

Waier, Phillip R. 2011. “Building Construction Cost Data.” Norwell, MA: R.S. Means. 


\section{Appendix A: Platt Bros. 85/15 Metallizing Wire Technical Data}

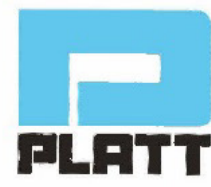

\section{Thermal \\ Spraying with \\ Plattzinc $_{\circledast} 85 / 15$ \\ Zinc/Aluminum Wire}

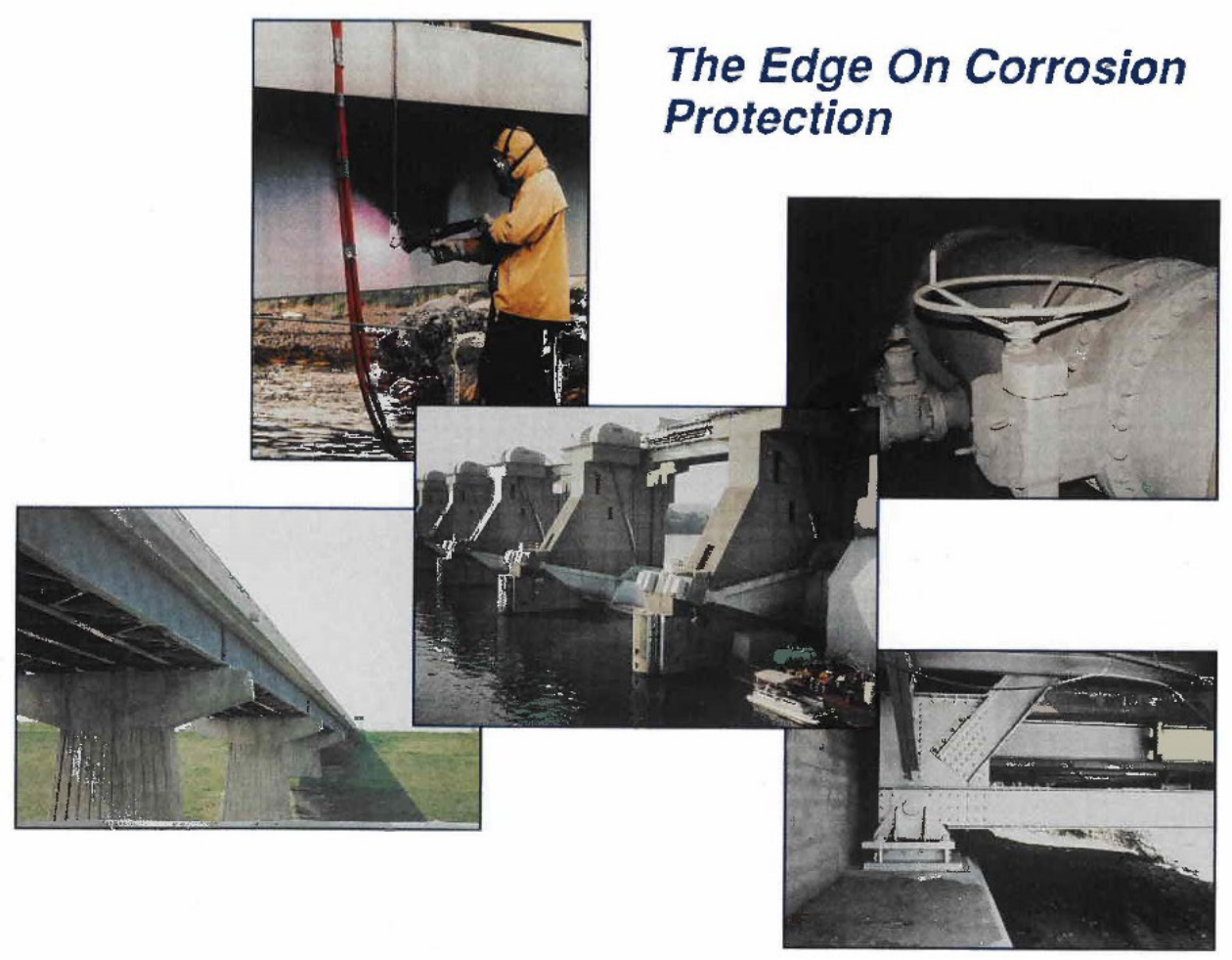




\section{Zinc/ Aluminum Combination}

Plattzinc $885 / 15$ is an alloyed wire of $85 \%$ zinc and $15 \%$ aluminum by weight. When thermally sprayed onto steel, the alloy produces a metallic coating incorporating the best characteristics of both metals for optimum corrosion protection.

\section{Dual Phased Coating}

Plattzinc $85 / 15$ combines the galvanic protection properties of zinc sacrificing itself in preference to the steel. The aluminum provides a passive barrier protection. Together, the zinc and aluminum provide an excellent corrosion resistant, thermal sprayed coating.

\section{One Application $=15+$ Years With No Maintenance}

Steel highway bridges throughout North America have been sprayed with Plattzinc $85 / 15$. The test of time has shown that the alloy of $85 \%$ zinc, $15 \%$ aluminum, sealed and unsealed, provides superior protection against sodium chloride or sulphur dioxide environments and the effects of marine exposure.

Thermal spraying with Plattzinc $85 / 15$ can be easily applied to a properly blasted surface up to a 20 mil thickness in just one application. Typically, one pass applies approximately 2 to 3 mils. No drying time is needed. The coating is dry on contact allowing sealers and/or topcoats to be applied immediately when specified.

\section{Plattzinc 85/15 Features}

- Lab tests have yielded bond strengths for Plattzinc $85 / 15$ of 3500 psi on properly prepared, grit blasted steel: higher than both pure zinc (1300 psi) and pure aluminum (2800 psi). Adhesion strengths will vary with application and equipment.

- Maximum Service Temperature is $600^{\circ} \mathrm{F}\left(315^{\circ} \mathrm{C}\right)$

- Spray deposit density of $95 \%$. Sealers and topcoats will adhere well due to the physical nature of the coating.

- Deposition rate efficiency of Plattzinc $85 / 15$ is higher than other materials. Coating coverage per pound sprayed is increased, thereby reducing overall spraying time and labor costs. Example: Spraying a thickness of $.006^{\prime \prime}$ : Zinc covers $3.5 \mathrm{sq}$. ft/lbs. $85 / 15$ covers $4.3 \mathrm{sq}$. ft/lbs.

- Plattzinc $85 / 15$ has excellent machinability, equivilant to aluminum and superior to pure zinc.

\begin{tabular}{|ll|}
\hline CHEMICAL COMPOSITION: & $\begin{array}{l}15 \% \text { Aluminum (tol. }+1-1 \% \text { ) } \\
\text { Balance Zinc }\end{array}$ \\
DENSITY: & .207 Lbs. per cubic inch. \\
DIAMETERS AVAILABLE: & $.079^{\prime \prime}, 091^{\prime \prime}\left(11\right.$ Gauge), 1/8" and $3 / 16^{\prime \prime}$ \\
PACKAGING: & 50 lbs coils \\
& 40 Lbs. plastic spools \\
& 450 lbs. payoffpak fiber drums. \\
\hline
\end{tabular}

Applications:

- Steel Infrastructure: Bridges, Walkways, Bridge Bearings Railings, Piers

- Waterways, Gates, Locks - Repair of Galvanized Coatings - Exterior of Steel and Iron pipes

- Gas Cylinders - Boat Trailers and other Marine equipment · Tanks 


\section{No Volatile Organic Compounds}

With Federal, State and local regulations limiting VOCs, durable, cost effective coating selection has become increasingly difficult. A thermally sprayed coating of Plattzinc $85 / 15$ has NO VOCs.

The Federal Highway Administration commissioned a test program in 1988 to investigate the performance of "low VOC" coating systems for bridges. Lab tests and long term natural field exposure testing was done and evaluated after 6 months, one, two, three and four years. Other natural exposure evaluations were done after 16 months. Among the coatings tested was Plattzinc 85/15. Tables $1 \& 2$ show the results of some popular systems with $<340 \mathrm{~g} / \mathrm{l}$ (low VOC).

The conclusions after 5 years of study were that both zinc and 85/15 provided excellent long term performance. In terms of rusting and undercutting at intentional scribes to the substrate, zinc and $85 / 15$ showed superior corrosion control and performed better than a majority of the paint systems tested. Based on this perfomance, the report stated that the thermal sprayed coatings appear to be the coating of choice on selected, highly corrosion prone bridge structures prior to erection or maintenance replacement.

Individual states have also conducted lab and field testing on Plattzinc 85/15. Their results favored field applied thermal spraying with $85 / 15$ over other maintenance options. The factors making a thermal spray coating attractive include;

- Existing paint is in poor condition.

- Bridge substructure is in good condition.

- Bridge deck is in good condition, new or recently rehabilitated.

- Steel is exposed to harsh salt spray or industrial atmospheres.

- High costs are anticipated for future maintenance operation.

Table 1 * 16 Month Natural Exposure Test $\%$ Rust

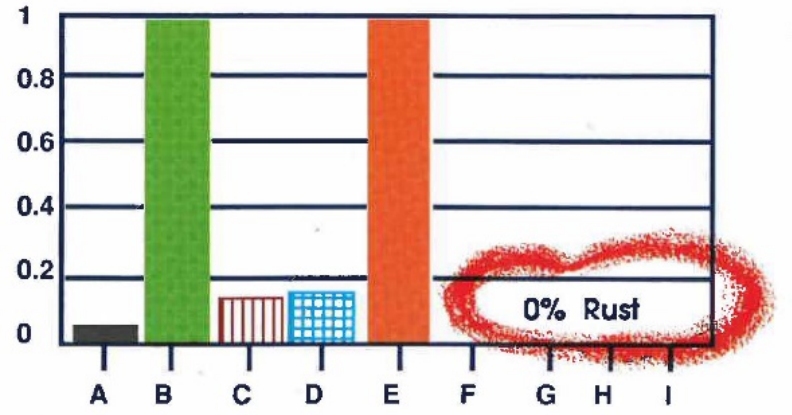

A Waterborne Inorganic Zinc $\mathbf{F}$ Zinc Thermal Spray (unsealed)

B Waterborne Zinc Acrylic

C Epoxy Mastic Urethane

D Epoxy Enamel

E Acrylic Latex
Table 2* 4 Year Natural Exposure Test

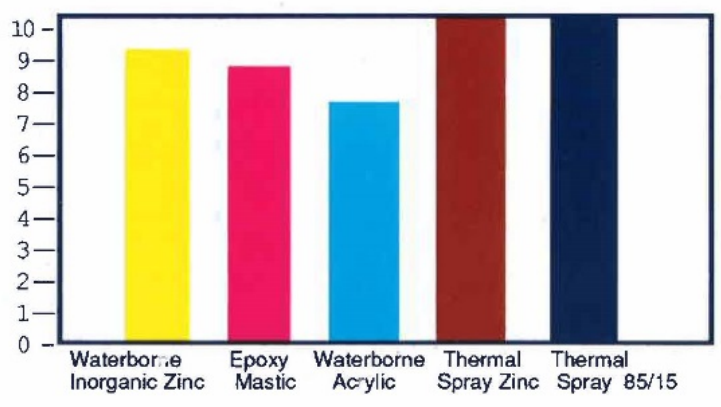

Average from 3 Test Sites:

Rusting Performance 1= poor, 10= excellent

* "Comparing the Performance of Metallized and Conventional Low VOC Coatings Applied to Steel in Marine Environments", R. Kogler and J. Peart, 1995. 


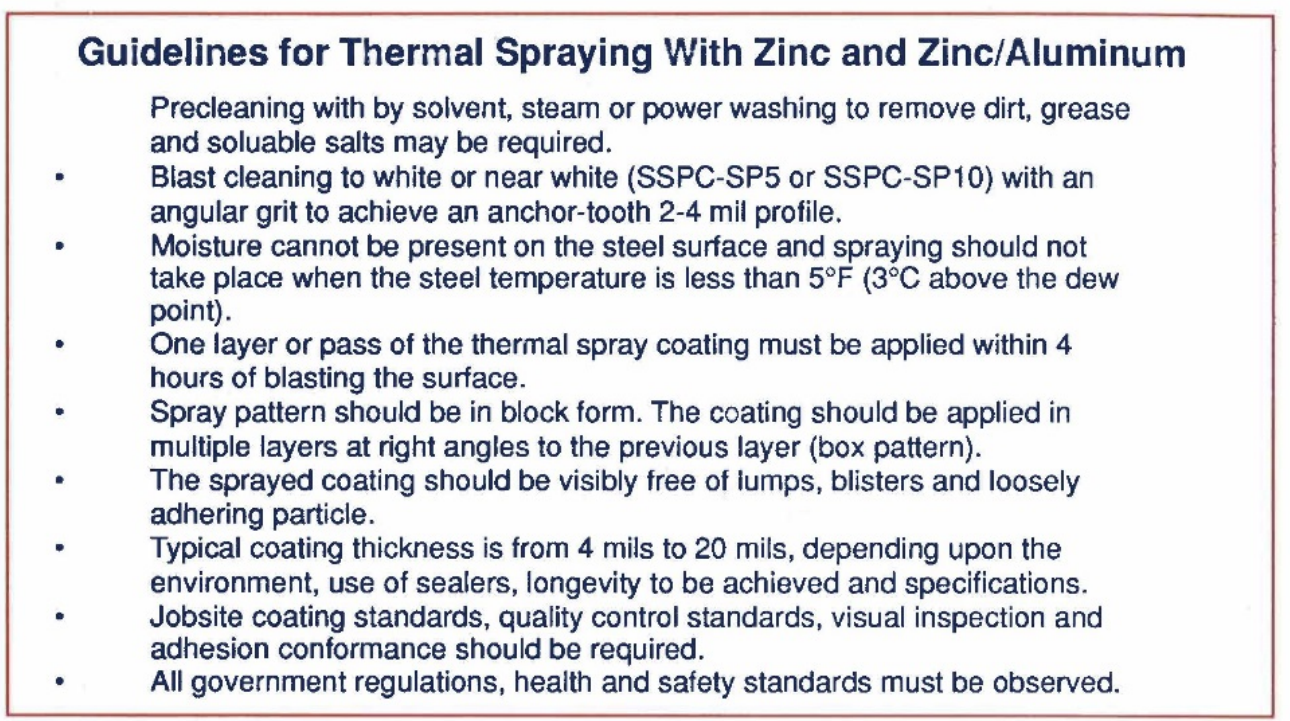

\section{Association Specifications Related to Thermal Spraying}

SSPC CS- Guide 23.00, June 1, 1991, Coating System Guide, Guide for Thermal Spray Metallic Coating Systems; Steel Structures Painting Council.

ASTM B833-93, Standard Specification for Zinc Wire for Thermal Spray, American Society for Testing and Materials. ASTM A780-90, Standard Practice for Repair of Damaged and Uncoated Areas of Hot Dip Galvanized Coatings,

American Society for Testing and Materials.

ASTM C633, Standard Test Method for Adhesion or Cohesive Strength for Flame Sprayed Coatings, American Society for Testing and Materials.

ANSI/AWS C2.20-9X, Specification for Zinc Thermal Spray Coatings for Reinforced Concrete, American Weiding Society.

ANSI/AWS A533-9X, Specification for Alloy Wires, Cored Wire and Ceramic Rods for Thermal Spraying, American Welding Society.

ANSI/AWS C2.18.93, Guide for the Protection of Steel With Thermal Spraying Coating of Aluminum and Zinc, American Welding Society

Mil 6712C, Military Specification, Wire, Metallizing.

CSA Standard G189, Reaffirmed 1992, Sprayed Metal Coating for Atmospheric Corrosion Protection, Canadian Standards Association.

ISO 2063, Metallic and other inorganic coatings - Thermal spraying. Zinc, aluminum and their alloys, International Standard, ANSI.

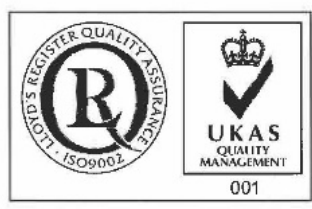

Quality Management System is ISO 9002 Registered/Certified.

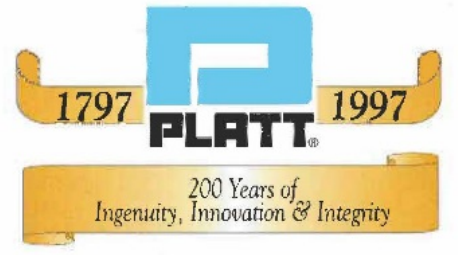

The Platt Brothers \& Company

2670 South Main Street, P.O. Box1030

Waterbury, Ct. 06721-1030

Phone: 203-753-4194 outside Ct 800-752-8276

Fax: 203-753-9709 www: Plattbros.com

This document, its contents and related information are submitted as suggestions with no warranty or other representation. The Platt Brothers \& Conpany shall have no liability of any kind, grants no license and assumes no responsibility as we have no control over the use of this information, environmental conditions, structure chosen for coatings or application of the products or procedures recommended herein. 


\section{Appendix B: Sherwin-Williams "SHER-CRYL" Topcoat Technical Data}

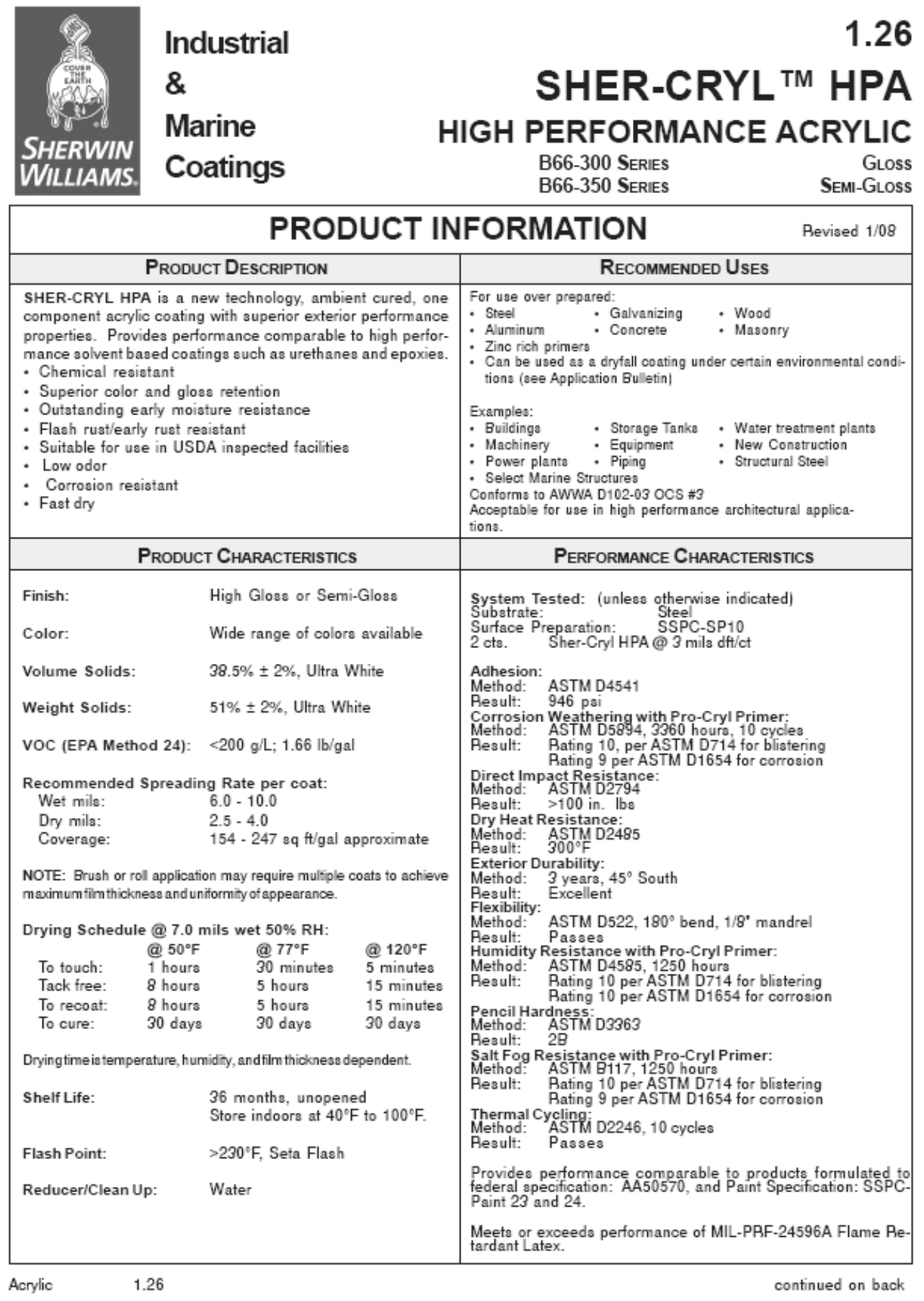




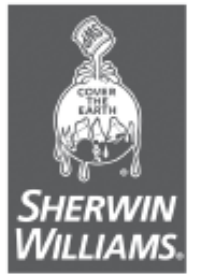

Industrial

\&

Marine

Coatings

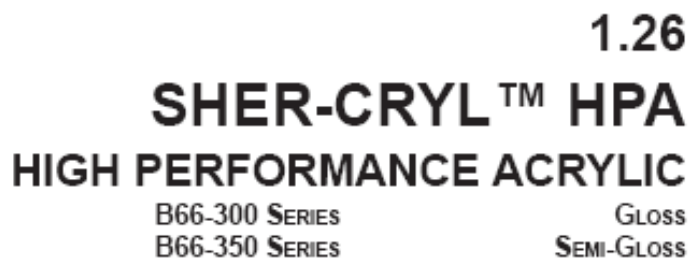

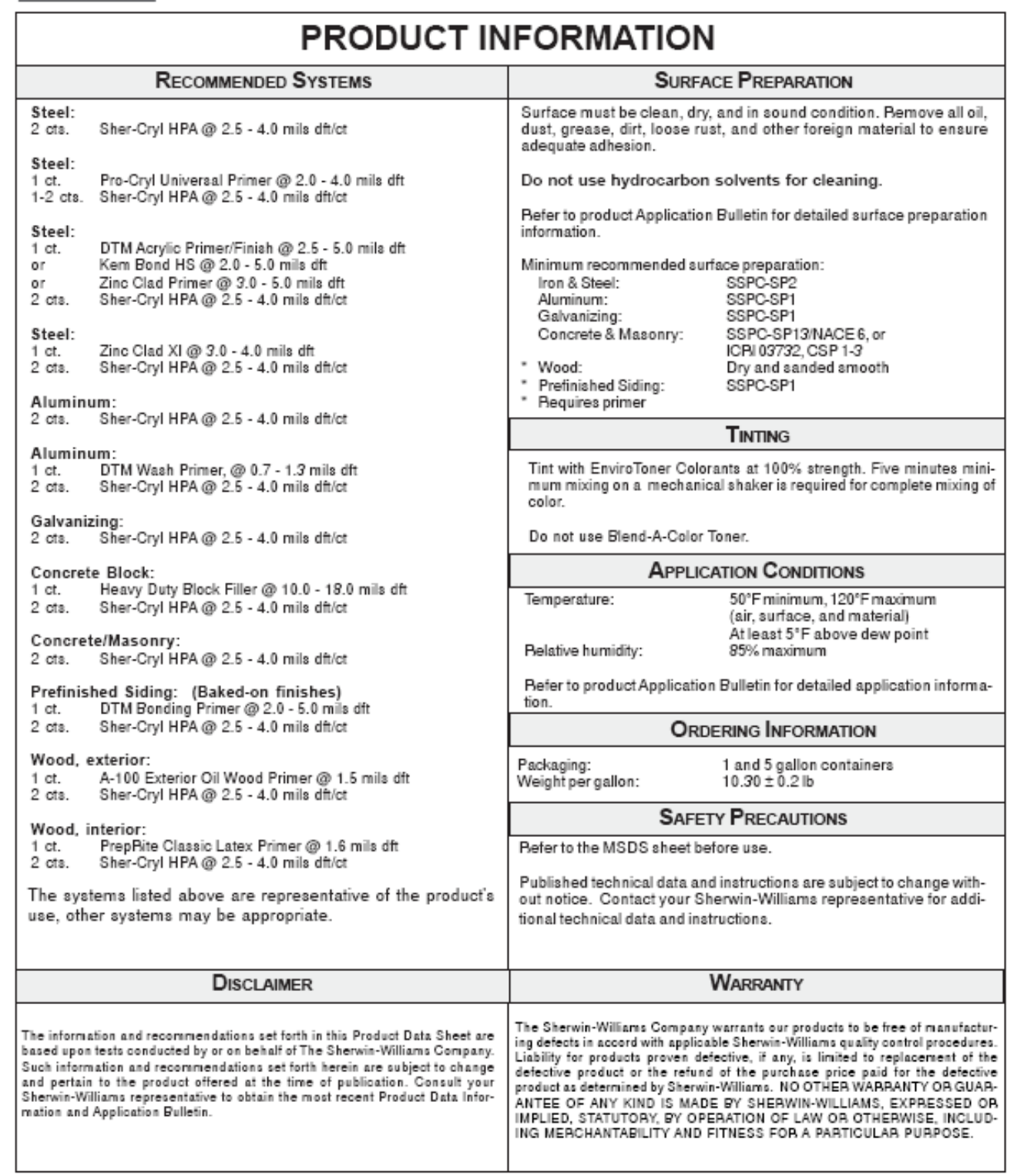




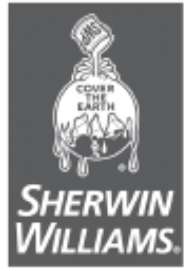

Industrial

\section{\&}

\section{Marine} Coatings

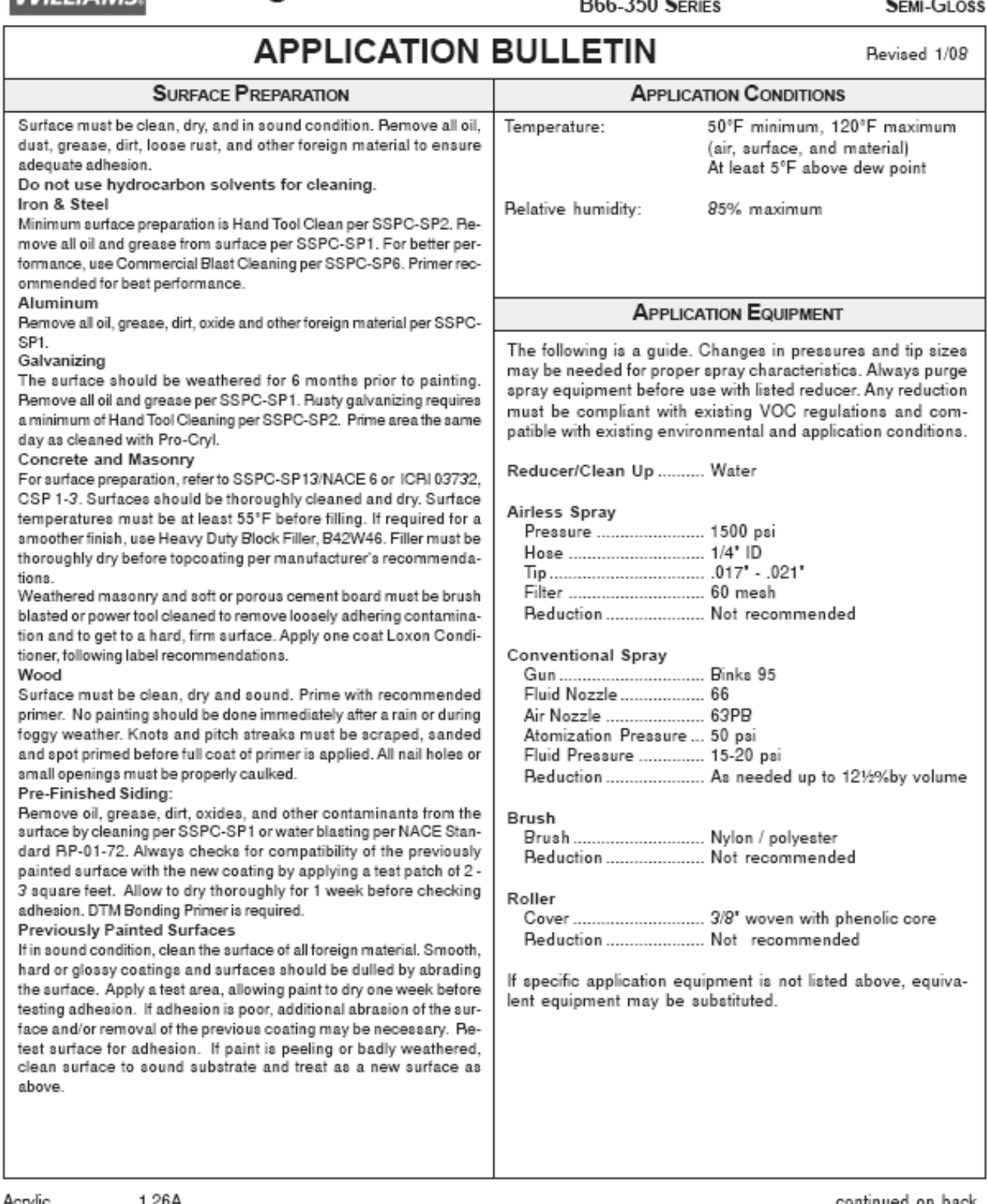

Acrylic 


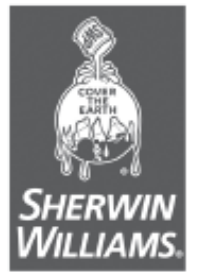

Industrial

\&

Marine Coatings

\section{$1.26 \mathrm{~A}$ \\ SHER-CRYL ${ }^{T M}$ HPA HIGH PERFORMANCE ACRYLIC \\ B66-300 Series \\ B66-350 Series \\ GLoss \\ Semi-Gloss}

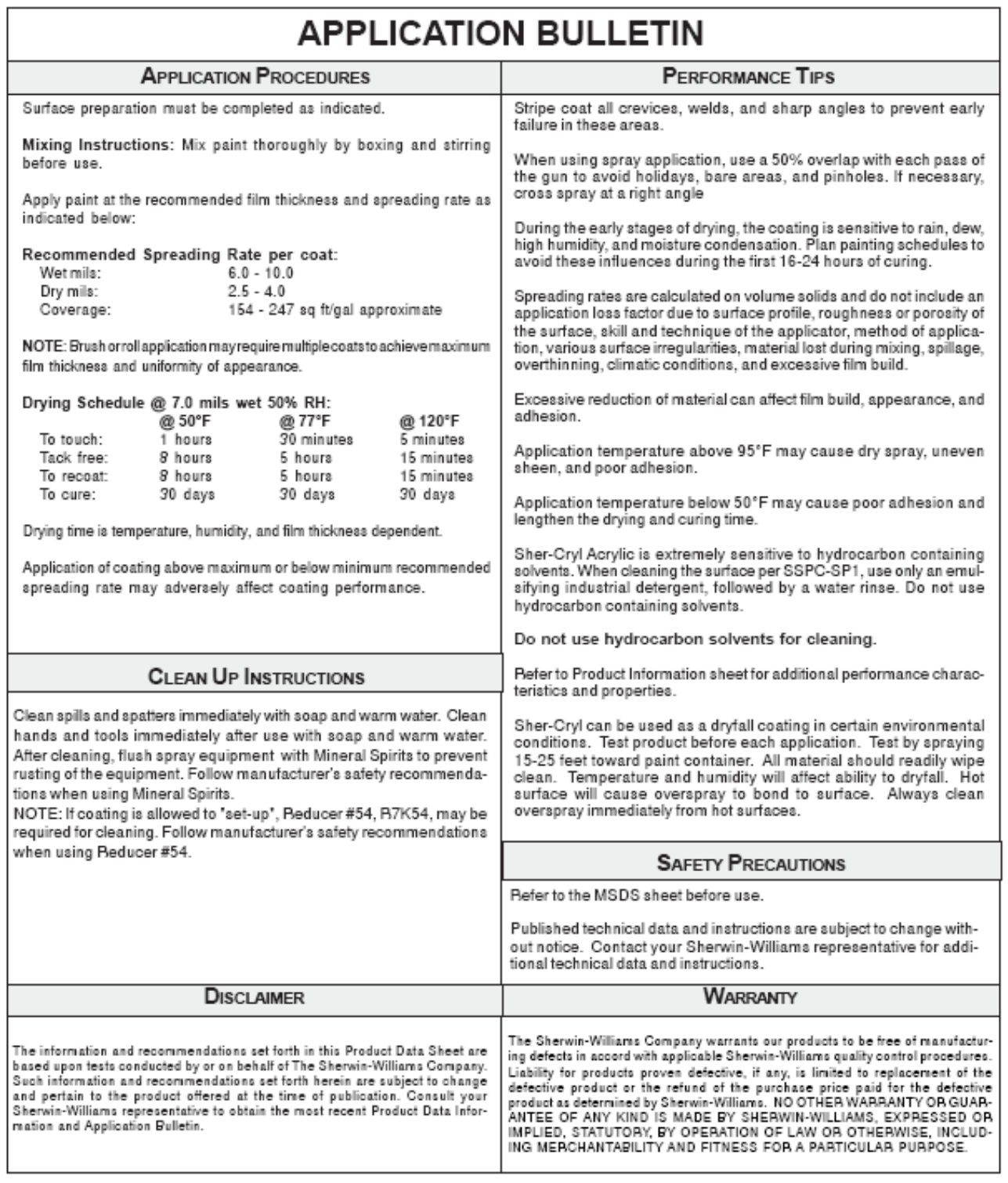




\section{Appendix C: Plascoat PPA 571 Ethylene Acrylic Acid-Modified Polyolefin Thermoplastic Powder}

\section{PLASCOAT PPA 571}

\section{Performance Polymer Alloy Coating}

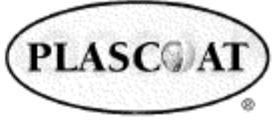

The Art of Protection

\section{TYPICAL PROPERTIES OF THE COATING}

The following data applies to a 350 micron coating applied under standard conditions onto $3 \mathrm{~mm}$ thick steel or aluminium. The pretreatment consisted of degreasing and gritblasting unless otherwise stated.

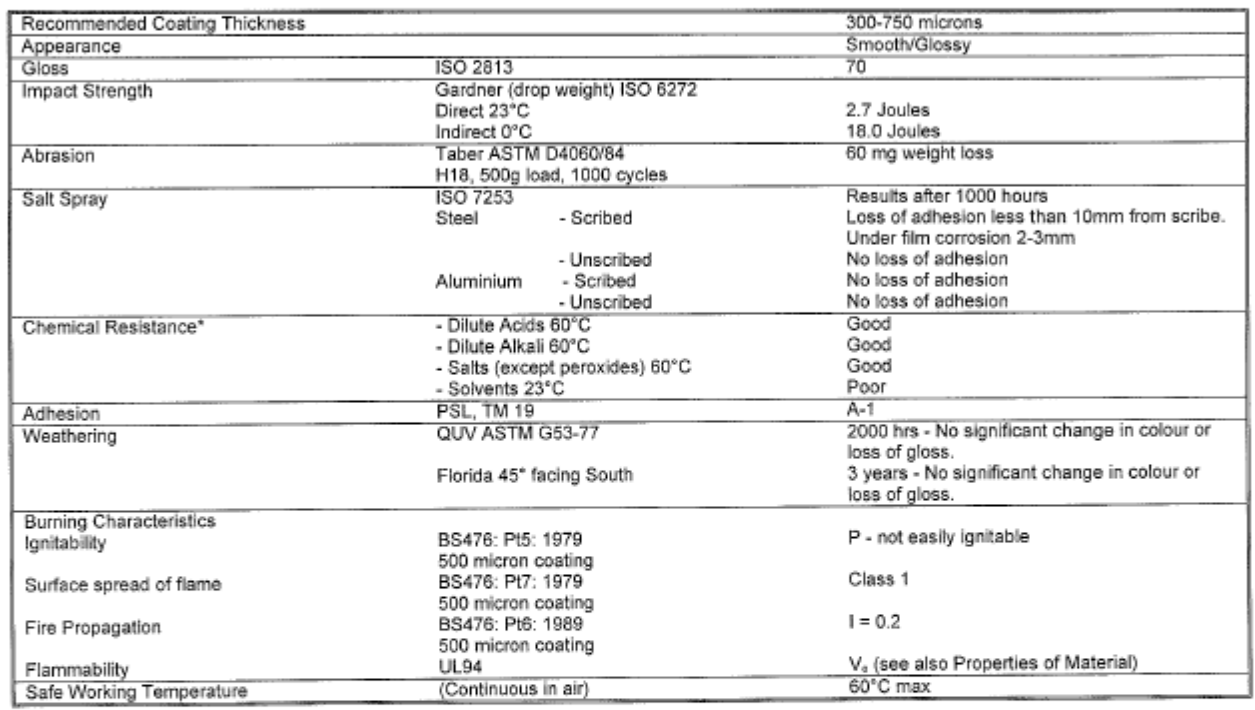

"Further technical advice may be obtained from Plascoat conceming the effects of particular chemicals or mixtures.

\section{QUALITY}

Plascoat is committed to the manufacture and supply of a wide range of thermoplastic coating powders. This service is backed by the unrivalled experience of over 40 years of powder coating application. With a policy of continuous improvement to its range of products. Plascoat reserves the right to alter of amend any item. Stringent quality control procedures are carried out at every relevant stage of manufacture and Plascoat operates a quality management system approved by BSI in accordance with ISO 9001:2000.

Plascoat Systems Limited Trading Estate, Farnham Surrey,

United Kingdom

United Kingdom
Tel: $+44(0) 1252733777$

ax. $+44(0) 1252721250$

Web site: www.plascoat.com

PPA571/11/06/03/WGO
Plascoat can also offer, through its many factories in Europe. specialist plastic coating equipment, an extensive custom coating service and a size reduction service for plastics and other materials.

Plascoat is a subsidiary member of the IPT Group of companies.

Plascoat is a UK registered trade name.

It should be appreciated that the information given here is, to the best of our knowledge, thue and accurate. However, since conditions under which our materials and equipment may be usod are boyond our
control, recommendations are macte without warranty or guarantee.

Plascoat Corp

Crown Center

5005 Rockside Rd

Cleveland

OH44131 U.S.

Tel: 8004897236

Fax: 2165201273

plascoationls.net
Plascoat Corp (Sales \& Dist)

Puncla Mercantile Inc

4115 Sherbrooke Str West,

Qth Floor, Montreal,

Call: 8004897236

Tel: +15149317278

Fax: +1 5149317200

sales@punda.com 


\section{PLASCOAT PPA 571}

\section{Performance Polymer Alloy Coating}

PLASCQAT

The Art of Protection

\section{GENERAL DESCRIPTION}

Plascoat PPA 571 has been specifically designed to provide a long lasting, tough coating for exterior applications to mild steel, galvanised steel and aluminium. It is based on an alloy of acid modified polyolefins. Therefore it is Halogen free and the combustion fumes are low in smoke and have a low toxicily index.

Plascoat PPA 571 is resistant to stress cracking, adverse weather conditions, detergents, salt spray and typical airborne pollutants. The coating maintains excellent adhesion to the metal substrate without the need for a separate primer. The material also provides a good degree of electrical insulation, abrasion and impact resistance.

PPA571 is normally applied by the Fluidised Bed process, but it can also be applied by Flock Spray.

\section{TYPICAL USES}

Fence posts, fencing panels, sign posts, street furniture, balustrading. stadium seating, pipes including potable water, cable tray and ducting. Garden furniture, gutter brackets and wirework.

\section{GUIDE TO TYPICAL COATING CONDITIONS}

Recommended Protreatment:

To get the full benefits of the material, mild steel should be blast cleaned to Swedish standard SA $2 \%-3$. Alternatively degreasing and Iron phosphating can be used.

For galvanised ateel the surface should be grit blasted with a fine non-ferrous medium at a low pressure. For maximum long term adhesion, a suitable phosphate or chromate system should be used.

For both types of metal surface, ensure any previously applied resin based pretreatment is removed before applying your own in-house pretreatment. Advice on this can be obtained from your pretreatment supplier.

Fluid Bed Batch Operation:

Metal preheat temperature $220^{\circ} \mathrm{C}-320^{\circ} \mathrm{C}$, depending on metal thickness. Dip for 3-5 seconds or as required to achieve the desired coating thickness. A post-heat cycle at $170^{\circ} \mathrm{C}$ may be required to develop fully the surface finish on thin items.

The process temperatures used should only be the minimum to achieve an acceptable surface finish. However to ensure optimum adhesion the metal temperature must exceed $150^{\circ} \mathrm{C}$. Overheating may cause the coating to discolour later in storage or in service.

Thicknesses outside the recommended range may be detrimental to the properties of the coating.

Flock Spray method:

After pre-treating the metal as above the substrate should be preheated to a metal temperature of 180 to $220^{\circ} \mathrm{C}$. To ensure optimum adhesion the metal temperature must exceed $150^{\circ} \mathrm{C}$. The PPA571 can then be sprayed onto the metal until the coating no longer melts. i.e. has a "sugar-like" appearance. The item is then returned to the oven to fully melt the coating. To obtain thicker coatings more powder can be sprayed onto the molten first coat and reheated. This process can be repeated until the required thickness is acheved.

For typical properties of the coating see overleaf

$\begin{array}{lr}\text { TYPICAL PROPERTIES OF THE POWDER } \\ \text { Coverage (100\% efficiency) } & 3 \mathrm{~m}^{2} / \mathrm{Kg} \text { at } 350 \text { microns } \\ \text { Particle Size } & 95 \% \text { less than } 250 \text { microns } \\ \text { Bulk Density (at rest)* } & 0.40 \mathrm{~g}^{\prime} / \mathrm{cm}^{3} \\ \text { Fluidising Characteristics } & \text { Excellent } \\ \text { Packaging } & 20 \mathrm{~kg} \text { cardboard boxes }\end{array}$

TYPICAL PROPERTIES OF THE MATERIAL

Specific Gravity*

Tensile Strength

Elongation at Break

Brittleness Temperature

Hardness

ISO 527

ISO 527

ASTM D-746

$0.96 \mathrm{~g} / \mathrm{cm}^{3}$

$14 \mathrm{MPa}$

$800 \%$

$-78^{\circ} \mathrm{C}$

Shore D

ISO 306

Melting Point

Tear Strength

Environmental

Stress Cracking

Toxicity Index

Flammability

Dielectric Strength IEC 243 VDE $0303 \quad 47.8 \mathrm{KV} / \mathrm{mm}$ at

ASTM D1938

44

$70^{\circ} \mathrm{C}$

$105^{\circ} \mathrm{C}$

22 N.mm

ASTM 01693 Greater than 1000 hrs NES 7

1.8

UL94 $3.2 \mathrm{~mm}$ moulding Unrated

(sce also Properties of Coating)

Surface Resistivity $\quad$ IEC $93 \quad 8 \times 10^{17} \mathrm{Ohm}$

at 350 microns

"These values may vary from colour to colour

\section{STORAGE}

Stored in a clean dry area at $10-25^{\circ} \mathrm{C}$ and out of sunlight, the material should not deteriorate. However, in the interest of good housekeeping, old stocks should be used first

\section{HEALTH AND SAFETY}

Plascoat PPA 571 is supplied as a finely divided powder. Whilst there are no known health hazards associated with PPA 571 normal handling precautions for dealing with fine organic powders should be taken - i.e excessive dust generation and inhaling of the powder should be avoided. Facilities may be required for removing excess dust from the working area during the coating of certain difflicult items.

As with all polymeric powders, the material can ignite if brought into contact with a high temperature source or ignition - particularly in the fluidised condition

Reference should be made to Plascoat Health and Safety Data Sheet HS504, available on request.

Should the coating be required for contact with food or potable water, further details should be obtained from Plascoat. 


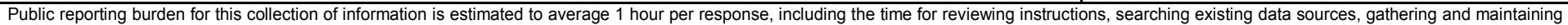

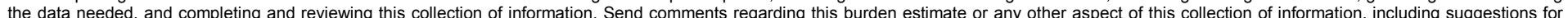

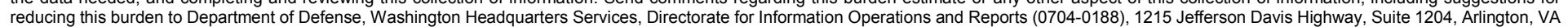

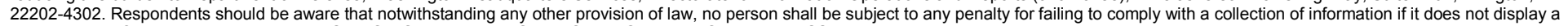
currently valid OMB control number. PLEASE DO NOT RETURN YOUR FORM TO THE ABOVE ADDRESS.
1. REPORT DATE (DD-MM-YYYY)
September 2017

\section{REPORT TYPE \\ Final Technical Report}

\section{TITLE AND SUBTITLE}

Demonstration of Thermally Sprayed Metal and Polymer Coatings for Steel Structures at

Fort Bragg, NC: Final Report on Project F07-AR10
3. DATES COVERED (From - To)

5a. CONTRACT NUMBER

5b. GRANT NUMBER

5c. PROGRAM ELEMENT NUMBER

Corrosion Prevention and Control

5d. PROJECT NUMBER

CPC F07-AR10

Larry D. Stephenson, Alfred D. Beitelman, Richard G. Lampo, Ashok Kumar, Douglas

Neale, Lawrence Clark, Karl Palutke, Michael Surratt, and David Butler 5e. TASK NUMBER

MIPR5CCERB1011, MIPR5CROBB1012

\section{5f. WORK UNIT NUMBER}

8. PERFORMING ORGANIZATION REPORT
NUMBER

ERDC/CERL TR-17-30

U.S. Army Engineer Research and Development Center

Construction Engineering Research Laboratory

P.O. Box 9005

Champaign, IL 61826-9005

9. SPONSORING / MONITORING AGENCY NAME(S) AND ADDRESS(ES)

Office of the Secretary of Defense (OUSD(AT\&L))

3090 Defense Pentagon

Washington, DC 20301-3090

10. SPONSOR/MONITOR'S ACRONYM(S)

OSD

11. SPONSOR/MONITOR'S REPORT NUMBER(S)

\section{DISTRIBUTION / AVAILABILITY STATEMENT}

Approved for public release; distribution is unlimited.

\section{SUPPLEMENTARY NOTES}

\section{ABSTRACT}

The Department of Defense spends billions annually on corrosion-related maintenance. It has recently been estimated that at least 25 U.S. Army installations have severe corrosion problems with above-ground steel storage tanks. Coatings are widely recognized as a "first line of defense" for protecting these steel structures. Thus, the Office of the Secretary of Defense Corrosion Prevention and Control Program sponsored a project that demonstrated and evaluated new technology with two thermally sprayed coating systems for corrosion protection of steel structures in severely corrosive environments. The technologies included metallizing a steel tank with zinc-aluminum alloy and flame-spraying a polyolefin powder coating on the legs of an elevated steel storage tank. This report documents the materials and application of the two coating systems and subsequent performance evaluations. Metallizing is more costly than traditional organic coatings and is often overlooked as an option. However, life-cycle costs in highly corrosive environments can actually be lower than using organic coating systems. As this project demonstrated, the flame-sprayed polyolefin coating is too costly for use on large steel structures. Guidance documents are identified to help make decisions on the use and procurement of metallizing coating systems. The project's return on investment was calculated to be 2.94 .

\section{SUBJECT TERMS}

Steel—Corrosion; Corrosion and anti-corrosives; Protective coatings; Metal spraying; Polyolefin coating; Flame spraying; Military bases, Fort Bragg (N.C.)

\begin{tabular}{|l|l|l|c|c|l|}
\hline \multicolumn{2}{|l|}{ 16. SECURITY CLASSIFICATION OF: } & $\begin{array}{c}\text { 17. LIMITATION } \\
\text { OF ABSTRACT }\end{array}$ & $\begin{array}{l}\text { 18. NUMBER } \\
\text { OF PAGES }\end{array}$ & $\begin{array}{l}\text { 19a. NAME OF RESPONSIBLE } \\
\text { PERSON }\end{array}$ \\
\cline { 1 - 2 } $\begin{array}{c}\text { a. REPORT } \\
\text { Unclassified }\end{array}$ & $\begin{array}{c}\text { b. ABSTRACT } \\
\text { Unclassified }\end{array}$ & $\begin{array}{c}\text { c. THIS PAGE } \\
\text { Unclassified }\end{array}$ & UU & 46 & $\begin{array}{l}\text { 19b. TELEPHONE NUMBER (include } \\
\text { area code) }\end{array}$ \\
\hline
\end{tabular}

